\title{
Onset and Progression of Human Osteoarthritis-Can Growth Factors, Inflammatory Cytokines, or Differential miRNA Expression Concomitantly Induce Proliferation, ECM Degradation, and Inflammation in Articular Cartilage?
}

\author{
Karen A. Boehme and Bernd Rolauffs * iD \\ G.E.R.N. Tissue Replacement, Regeneration \& Neogenesis, Department of Orthopedics and Trauma Surgery, \\ Medical Center-Albert-Ludwigs-University of Freiburg, Faculty of Medicine, Albert-Ludwigs-University of \\ Freiburg, 79085 Freiburg im Breisgau, Germany; karen.boehme@web.de \\ * Correspondence: berndrolauffs@googlemail.com; Tel.: +49-761-270-26101
}

Received: 3 July 2018; Accepted: 1 August 2018; Published: 3 August 2018

\begin{abstract}
Osteoarthritis (OA) is a degenerative whole joint disease, for which no preventative or therapeutic biological interventions are available. This is likely due to the fact that OA pathogenesis includes several signaling pathways, whose interactions remain unclear, especially at disease onset. Early OA is characterized by three key events: a rarely considered early phase of proliferation of cartilage-resident cells, in contrast to well-established increased synthesis, and degradation of extracellular matrix components and inflammation, associated with OA progression. We focused on the question, which of these key events are regulated by growth factors, inflammatory cytokines, and/or miRNA abundance. Collectively, we elucidated a specific sequence of the OA key events that are described best as a very early phase of proliferation of human articular cartilage (AC) cells and concomitant anabolic/catabolic effects that are accompanied by incipient pro-inflammatory effects. Many of the reviewed factors appeared able to induce one or two key events. Only one factor, fibroblast growth factor 2 (FGF2), is capable of concomitantly inducing all key events. Moreover, AC cell proliferation cannot be induced and, in fact, is suppressed by inflammatory signaling, suggesting that inflammatory signaling cannot be the sole inductor of all early OA key events, especially at disease onset.
\end{abstract}

Keywords: early osteoarthritis; articular cartilage; proliferation; fibroblast growth factor 2; mitogen activated protein kinase; transforming growth factor $\beta$; SMA- and MAD-related protein; interleukin; nuclear factor kappa B; miRNA

\section{Introduction}

Osteoarthritis (OA) is a complex degenerative disease of the whole joint leading to progressive articular cartilage (AC) destruction. Even though multiple treatment guidelines have been proposed [1-3], no effective measures exist for the prevention of primary OA. True disease-modifying therapies for $\mathrm{OA}$ in the sense of a causal treatment are still missing. However, it is generally accepted that the level of damage occurring in early $\mathrm{OA}$ is potentially reversible [4] and that a better insight into the early OA mechanisms is likely the key for developing diagnostic strategies and targeted therapies $[5,6]$.

AC features a specialized architecture consisting of superficial (SZ), middle (MZ), and deep (DZ) zones $[7,8]$, which are formed by modulation of the phenotype of the epiphyseal cartilage cells during skeletal growth and maturation [9]. Of particular interest, it has been shown that, when human 
AC samples are fluorescence-tagged and viewed from above, the cells exhibit complex patterns of arrangement in the surface layer of the superficial zone and with an orientation parallel to the joint surface, a feature that has been called superficial cell spatial organization (SCSO) $[10,11]$. The human SCSO can be highly dynamic, as horizontally orientated cell strings, for example in intact knee AC progress in early OA into double strings, together with an increased SZ cell density suggesting AC cell proliferation, are typical [12]. With OA progression, cell clusters occur, which are ultimately succeeded by a diffuse cell arrangement that is lacking any discernable organization [10,13]. A hallmark of early OA is proliferation of AC-inherent cells $[10,13,14]$, which can be linked to these predictable SCSO changes (see Figure 1) through experimentally inducing AC cell proliferation in early OA AC explants beneath the joint surface. Indeed, proliferation induced via fibroblast growth factor 2 (FGF2) recapitulated SCSO loss and generated a structural AC phenotype that was comparable to advanced OA [13]: human AC explants containing strings and early OA-typical double strings oriented parallel to the surface altered their SCSO through induced proliferation into a diffuse arrangement lacking any discernable organization. Thus, early OA proliferation of SZ cells has a major impact on AC architecture. Moreover, AC cells that transiently proliferate during early OA and form clusters at the margins of extracellular matrix (ECM) fibrillation [14-16] express a large number of proteins that are involved in proliferation, ECM-degradation, and incipient inflammation [14,17], which illustrates the signaling complexity of early OA.

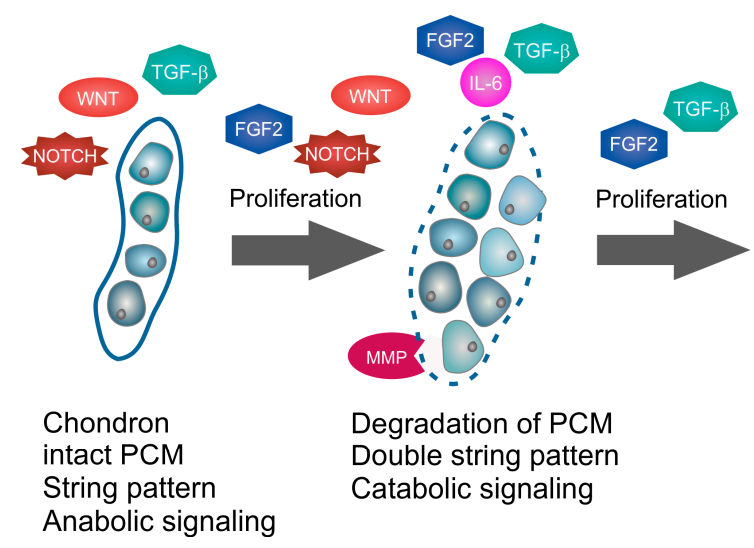

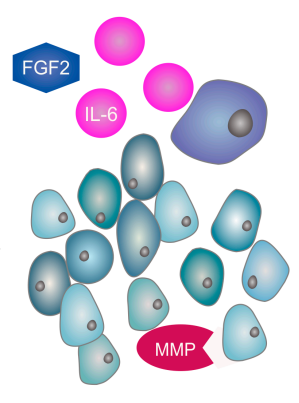

Cell cluster Catabolic signaling Inflammation

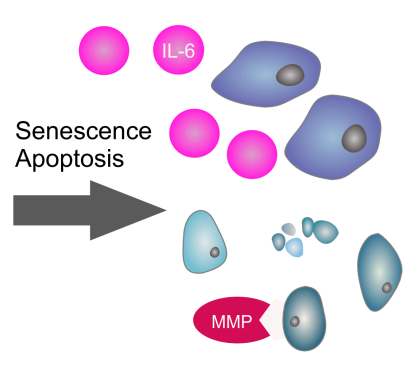

Loss of pattern Catabolic signaling Inflammation

Figure 1. Human osteoarthritis onset and progression. Illustration of the relationship of signaling and superficial cell spatial organization (SCSO). Overview about key proteins in relation to changes in the SCSO of human articular cartilage (AC), which is based on the subsequent chapters that provide a detailed review of the individual pathways. In the superficial zone (SZ) of normal human adult AC differentiated chondrocytes are arranged in string patterns embedded in the pericellular matrix (PCM) and mediate extracellular matrix (ECM) maintenance. The onset of osteoarthritis (OA) is characterized by proliferation. During formation of double string patterns, the PCM is progressively degraded, presumably by MMPs and other catabolic factors. Proliferation in early OA is dependent on fibroblast growth factor 2 (FGF2), transforming growth factor $\beta$ (TGF- $\beta$ ), wingless-type MMTV integration site family (WNT), and notch homolog (NOTCH) signaling, whereas catabolic matrix metalloproteinase (MMP) expression is mediated by FGF2, a switch in TGF- $\beta$ signaling and inflammatory cytokines including IL-6. Subsequently, the processes maintaining sustained proliferation and ECM degradation lead to formation of cell clusters that develop from double strings. At the stage of SCSO clusters, pronounced inflammation outweighs attenuated growth factor impact. Late stage OA, accompanied by macroscopic ECM erosion, is characterized by senescence and apoptosis of cartilage-inherent cells and predominance of inflammation.

Indeed, research aimed at establishing a unified theory of the initial OA dysfunction so far has not been successful [18] and this is likely connected to the fact that OA pathogenesis includes several pathways, whose interactions remain unclear, especially at the onset of the disease [19]. 
The current review focused on the relationship between the signaling pathways that are associated with rarely considered proliferation of human AC cells in early OA and the anabolic, catabolic and pro-inflammatory effects that are well-established and have been associated with OA progression. More specifically, the review focused on the questions, which of the three key events in AC-proliferation, ECM degradation, and inflammation - are inducible by growth factor signaling, inflammatory cytokine signaling, and/or miRNA regulation. Additionally, we aimed to reveal in which sequence(s) these events can and cannot occur, and whether we can identify a single factor that is able to induce all of these key events, according to the currently available knowledge.

The two most examined pro-inflammatory cytokines in early OA are Interleukin-1 beta (IL-1 $\beta$ ) and tumor necrosis factor $\alpha$ (TNF- $\alpha$ ) [20] but various other pro-inflammatory cytokines and chemokines such as IL-6, IL-8, and IL-17 may also be involved in early OA pathology [20,21]. Proliferation of AC cells is modulated by fibroblast growth factor 2 (FGF2) [22,23] and transforming growth factor $\beta$ (TGF- $\beta$ ) [24] signaling, in addition to many other effects. Therefore, particularly FGF2, TGF- $\beta$, and inflammatory cytokine signaling in combination with their miRNA regulation in human AC have been reviewed.

\section{Fibroblast Growth Factor 2 Signaling}

FGF2 is participating in several signaling pathways regulating proliferation, migration, inflammation, angiogenesis, differentiation, and senescence [22,23]. FGF2 is produced endogenously in human AC and occurs bound to perlecan, a heparan sulfate proteoglycan (HSPG) in the pericellular matrix (PCM) [25] (see Figure 2). Upon cutting of human AC, FGF2 is released from the PCM, activating mitogen activated protein kinase (MAPK) signaling [26]. Interestingly, FGF2 induces proliferation in both human intact and OA AC [27]. Moreover, FGF2 transduction of human knee AC samples is capable of recapitulating SCSO changes observed in early OA by inducing AC cell proliferation, which cumulates in complete SCSO loss comparable to an advanced OA-like structural phenotype of human AC [13]. In addition, FGF2 expression has been described as a marker of the human AC mesenchymal stem and progenitor cell (MSPC) population and is implicated in MSPC proliferation and chondrogenesis [23]. Besides, FGF2 acts as a chemo-attractant for monocytes and can be released by a variety of immune cells [28]. The FGF2 concentration in plasma and knee synovial fluid (SF) of OA patients is approximately twice of that of patients with normal healthy knee joints. Moreover, the increase of FGF2 abundance in OA plasma and SF correlates positively with radiographic OA severity [29]. Cells in human healthy and OA AC express all four fibroblast growth factor receptors (FGFR), but FGFR1 and FGFR3 dominate by far, compared to FGFR2 and FGFR4 [30,31]. Moreover, in human OA AC cells FGFR1 expression is increased while FGFR3 is concomitantly suppressed, compared to healthy AC cells [30].

In monolayer cell cultures established from human healthy AC, rFGF2 stimulation independently activates both protein kinase $C \delta$ (PKC $\delta$ ) and rat sarcoma viral oncogene homolog (RAS) signaling cascades [32] predominantly via FGFR1 [33]. In parallel, the extracellular signal-regulated kinase (ERK), p38, and JUN N-terminal kinase (JNK) MAPK pathways are activated by PKC $\delta$ [32], whereas RAS predominantly activates the ERK signaling cascade [34] (see Figure 2). ERK phosphorylation is enhanced in human OA AC compared to healthy AC $[35,36]$. Moreover, human OA AC shows higher phosphorylated and therefore activated p38 MAPK level compared with normal AC [36,37]. Also, JNK activation is enhanced in human OA AC, compared to healthy control AC [36]. Notably, the highest phosphorylation of all MAPKs is found in the SZ of both healthy and OA AC [38].

The MAPK signaling cascade appears to be the dominating pathway responsible for matrix metalloproteinase (MMP)- 1 and MMP-13 mRNA and protein expression in human healthy and OA AC cells in response to rFGF2 [32,39]. MMP-13 transcription in human (OA) AC cells in response to rFGF2 can be mediated by the transcription factor ETS-domain protein ELK-1 (ELK1) [32,35]. rFGF-2 dependent upregulation and activation of MMP-9 regulated by RAS and PKC $\delta$ dependent MAPK activation has been reported utilizing a human breast cancer cell line, whereas MMP-2 is not affected 
by rFGF2 in these cells [40]. In addition, in rat costal chondrocytes, rFGF2 dependent activation of MMP-9 has been reported [41]. Yet, in human AC, the impact of FGF2 induced MAPK signaling on MMP-2 and MMP-9 expression and activation has not been elucidated so far.

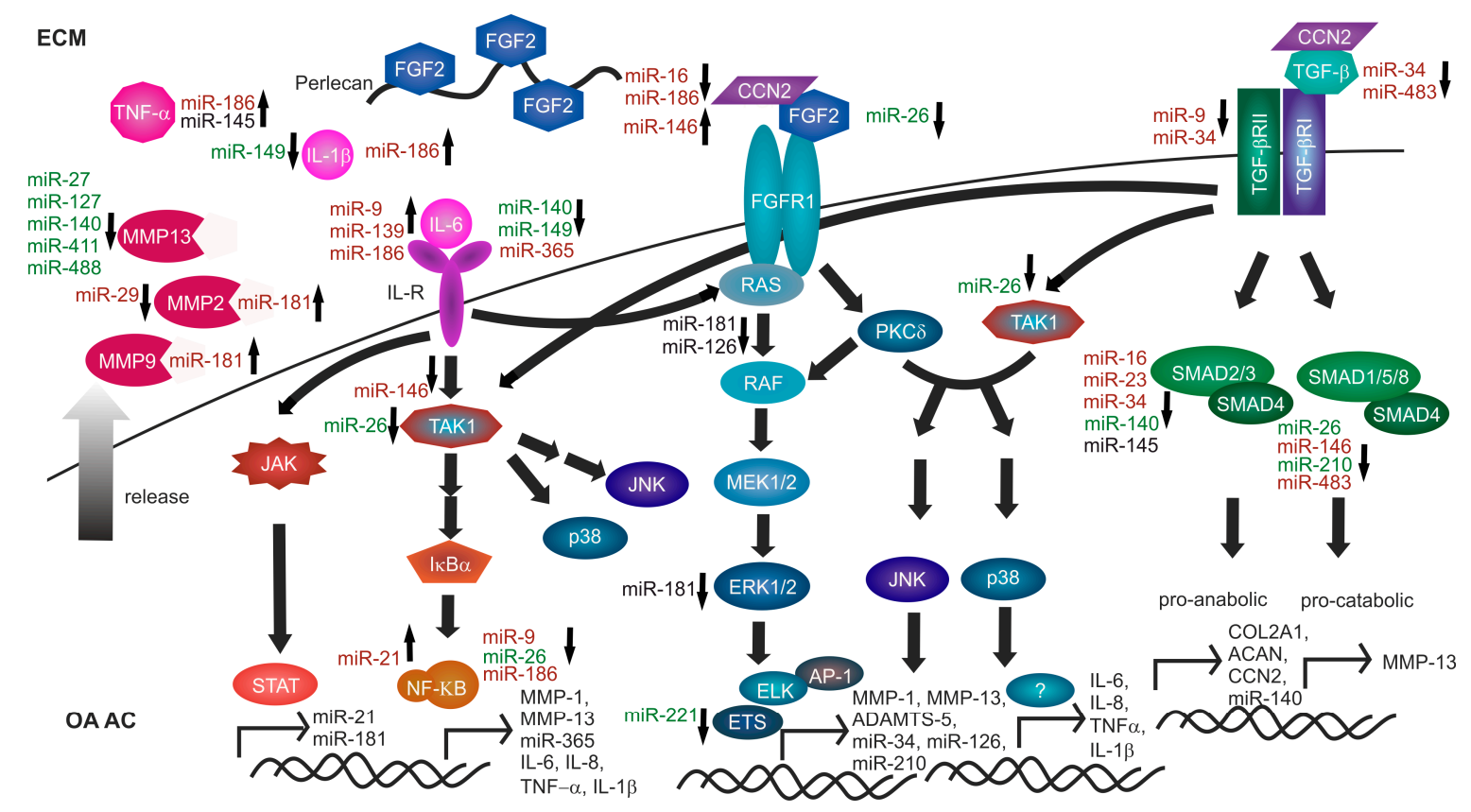

Figure 2. FGF2, TGF- $\beta$ and inflammatory cytokine induced catabolic and pro-inflammatory signaling in human OA AC. The major components of inflammatory cytokine, FGF2 and TGF- $\beta$ activated nuclear factor kappa $\mathrm{B}(\mathrm{NF}-\mathrm{kB})$, mitogen activated protein kinase (MAPK), and SMA- and MAD-related protein (SMAD) signaling as well as their transcriptional targets in human OA AC are depicted. Micro RNAs (miRNAs) upregulated in human OA AC are indicated in red, miRNAs downregulated in human OA AC are indicated in green. For miRNAs with contradictory regulation a black font is chosen. The small arrows beside the miRNAs pointing downwards indicate direct or indirect inhibition of the signaling component by the miRNA, whereas small upward arrows indicate direct or indirect activation of the signaling component by the miRNA. As illustrated, there is an intense crosstalk between the individual pathways. In human OA AC, expression of pro-catabolic target genes is mediated by NF- $\mathrm{B}, \mathrm{MAPK}$ and SMAD signaling, whereas pro-inflammatory targets are activated downstream of MAPK and NF- $\mathrm{KB}$ signaling. Advanced stages of $\mathrm{OA}$ are characterized by activation of inflammatory cytokine signaling. On miRNA level there is primarily a net upregulation of IL-6, whereas both positive and negative regulation of NF- $\mathrm{KB}$ signaling is reported. Moreover, in human OA AC upregulation of CCN2 and significantly enhanced activation of extracellular signal-regulated kinase (ERK), JUN N-terminal kinase (JNK) and p38 MAPK pathways has been documented. Yet, evidence for ERK signaling regulation by miRNA is contradictory, whereas JNK and p38 activation is a common downstream event after inflammatory cytokine, FGF2 and TGF $\beta$ pathway activation with no direct miRNA regulation reported in OA AC to date. TGF- $\beta$ signaling is globally downregulated in OA AC with especially negative regulation of the anabolic SMAD3 mediated pathway which is both evident on protein and miRNA level. In addition, in particular at miRNA level, reversal of negative regulation of MMP-13 is obvious in OA AC.

In cells isolated from human macroscopically healthy AC and OA AC, rFGF2 also suppresses expression of aggrecan (ACAN) and collagen type II $\alpha 1$ chain (COL2A1) [30,39]. Important in the context of this review, $r F G F 2$ promotes the expression of the inflammatory cytokines TNF- $\alpha, I L-1 \beta, I L-6$, IL-8, and monocyte chemotactic protein 1 (MCP-1), also known as C-C motif chemokine ligand 2 (CCL2) [32], highlighting an important pro-inflammatory role of FGF2. Moreover, rFGF2 upregulates runt related transcription factor 2 (RUNX2) activity in bovine, murine and human cells of different mesenchymal tissue origin, which, in turn, controls collagen type $X \propto 1$ chain (COL10A1), MMP-13 and A disintegrin 
and metalloproteinase with thrombospondin motifs (ADAMTS)-5 at the level of transcription [42-45]. Interestingly, treatment of human AC cells from young and healthy donors (Collins grade 0 or $1,<35$-year-old) with rFGF2 shows no significant anti-anabolic or catabolic effect; rFGF2 fails to repress ACAN expression or induce MMP-13 and ADAMTS- 5 expression in these cells. By contrast, notable effects on expression of these genes are observed when the same dose of rFGF2 is applied to damaged AC from older donors (grade 2 or higher, $>40$-year-old) [33]. These findings suggest a contextual property of FGF2 in AC biology, probably mediated by changes in abundance and activity of FGFR and other downstream components of FGF2 signaling. Constitutive rFGF2 expression after recombinant adeno-associated virus (rAAV)-hFGF2 transduction of human early OA AC explants induces cell proliferation within the native tissue [13]. Also, in monolayer cultures of human OA AC cells, rFGF2 enhances proliferation and prevents cell death [46].

In contrast to the above discussed human signaling profile showing predominant expression of FGFR1 and FGFR3, in murine healthy and surgically induced OA AC Fgfr2 and Fgfr4 are predominantly expressed, while Fgfr3 is barely detectable [31]. Surgical induction of OA in murine AC slightly reduces the expression of all Fgfr subtypes, but $\mathrm{rFgf2}$ local injection markedly induces Fgfr3 expression, which is opposite to the human OA scenario [30,31], where rFGF2 selectively reduces FGFR3 expression. Indeed, Fgf2 has anabolic functions in murine AC that are mediated by Fgfr3. This is in strong contrast to the rFGF2-mediated anti-anabolic and catabolic in human aged healthy and OA AC [34]. In murine OA models rFgf2 mediates proteoglycan deposition in AC [31,47]. In addition to its species-dependent effects, the AC protective activity of rFGF2 in animal models appears to be age-dependent, too, as seen in rabbit [48] and bovine AC [49], where the anabolic activity is restricted to AC from young animals. Moreover, in calf AC only low doses of $3 \mathrm{ng} / \mathrm{mL}$ FGF2 induce proliferation, whereas higher doses of 30-300 ng have no mitotic effect [49]. FGF2 adaptor proteins like CCN2, also known as connective tissue growth factor (CTGF), may fine tune FGF2 signaling in mammalian AC [41]. CCN2 mRNA and protein overexpression has been shown in human OA AC compared to healthy AC [50,51].

Thus, FGF-2 mediates proliferation, anti-anabolism, and catabolism in human AC. However, healthy cells of young donors appear to be resistant against the catabolic effects of FGF2. The important ability of FGF2 to induce inflammatory cytokine expression in human AC cells isolated from macroscopically healthy, but aged AC may be sufficient to induce or reinforce inflammation, dependent on the context and, thus, trigger OA progression.

\section{Transforming Growth Factor $\beta$ Signaling}

TGF- $\beta$ family ligands are growth factors basically implicated in proliferation, differentiation, and ECM maintenance. Binding to their hetero-tetrameric receptor, consisting of type I and type II subunits (TGF- $\beta$ R1, TGF- $\beta$ R2), activates TGF- $\beta$ signaling [24]. Expression of the three TGF- $\beta$ isoforms and both receptor subtypes has been examined in human OA AC compared to macroscopically healthy AC. However, the results are contradictory. While an upregulation of TGF- $\beta 1$, TGF- $\beta 3$, and TGF- $\beta$-R2 proteins with increased severity of OA has been reported in hip AC [52,53], downregulation of TGF- $\beta 1$ protein in knee OA AC has been observed [54]. In addition, a polymorphism in the asporin (ASPN) gene, leading to reinforced TGF- $\beta 1$ inhibition, has been associated with increased OA susceptibility $[55,56]$. Also, a single nucleotide polymorphism (SNP) in the SMA- and MAD-related protein 3 (SMAD3) gene has been linked with an increased risk of hip and knee OA [57].

In healthy adult AC cells all TGF- $\beta$ isoforms induce proliferation, with an age dependent decline in responsiveness [58]. Moreover, anabolic expression of COL2A1 and ACAN has been reported in response to rTGF- $\beta 1$ and rTGF- $\beta 2$ in human healthy AC cells [59] (see Figure 2).

Studies with human OA AC cells show that in OA TGF- $\beta$ signals predominantly through activin receptor-like kinase 1 (ALK1)/activin A receptor like type 1 (ACVRL1) SMAD1/5/8 pathways, which is linked to the induction of catabolism; e.g., MMP-13 expression [60,61]. Indeed, it is commonly suggested that ageing or onset of OA switch the receptor in TGF- $\beta$ signaling from the classical 
ALK5/TGF- $\beta$-R1 activated Smad2/3 signaling to TGF- $\beta$-R1 family member ALK1/ACVRL1 induced SMAD1 $/ 5 / 8$ signaling, which converts TGF- $\beta$ function in AC from an anabolic growth factor into a catabolic cytokine [62].

However, in OA AC both ALK1 and ALK5 expression appears to be largely reduced compared to healthy AC, although with a relative ALK1 excess [63]. rAAV-mediated TGF- $\beta$ expression induces proliferation and proteoglycan deposition in both human healthy and OA AC cells, while increasing both ALK1 and ALK5 expression, leading to an elevated, balanced receptor expression in OA AC cells resembling healthy AC. Indeed, MMP-13 protein expression is largely reduced in OA AC cells by this approach, while COL2A1 expression increases, indicating simultaneous anabolic and anti-catabolic actions of prolonged TGF- $\beta$ expression in human OA AC [63].

Although SMAD signaling is dominating in the TGF- $\beta$ response, additional downstream signaling includes activation of TGF- $\beta$-activated kinase-1 (TAK1), also known as mitogen-activated protein kinase kinase kinase 7 (MAP3K7), which acts as upstream activators of MAPK signaling and nuclear factor kappa B (NF-kB) signaling in OA AC, though its role in human AC is not well-investigated $[64,65]$. Moreover, $\mathrm{CCN} 2$ is a transcriptional target of TGF- $\beta$ and MAPK signaling. Interestingly, in human fibroblast cultures CCN2 is necessary for the TGF- $\beta$ induced phosphorylation of SMAD1 and ERK1/2, but it is dispensable for activation of the SMAD3 pathway [66]. Yet, in human AC implication of these pathways in CCN2 expression has not been validated so far [67].

Summarized, in human healthy AC TGF- $\beta$ signaling induces proliferation and anabolic gene expression via ALK5, a function which declines with increasing age. In contrast, in OA AC a pathway switch to ALK1 receptor converts TGF- $\beta$ from an anabolic cytokine into a catabolic factor promoting AC degradation. In the context of inflammation, TAK1 activation, a downstream event of several signaling pathways including FGF2 or TGF- $\beta$ signaling (Figure 2) has the potential to induce pro-inflammatory gene expression. Indeed, in a rat OA model, intra-articular injection of Tak 1 adenovirus induced the secretion of several pro-inflammatory interleukins in the synovial fluid [68]. However, until today, no pro-inflammatory function of TGF- $\beta$ signaling has been determined in human AC.

\section{Additional Growth Factor Signaling Pathways in Human Adult AC}

In addition to FGF2 and TGF- $\beta$ signaling, several other growth factors and their downstream pathway components appear to be expressed in human adult AC. The differential regulation of these growth factor-induced signaling pathways as well as their impact on proliferation, anabolic/catabolic gene expression, or inflammation in human OA AC is summarized in this chapter.

\subsection{WNT Signaling}

Evidence for progressive activation of the non-canonical $\mathrm{Ca}^{2+} /$ wingless-type MMTV integration site family (WNT) signaling pathway in human OA AC is provided by increased expression of WNT5A mRNA and protein [69-71] as well as CaMK2 nuclear factor of activated T-cells 5, tonicity-responsive (NFAT5), and nuclear factor of activated T-cells 2 (NFATC2) mRNA [70]. WNT5A protein expression in healthy human $\mathrm{AC}$ is restricted to the $\mathrm{SZ}$, whereas in $\mathrm{OA} \mathrm{AC}$ also cells of the deeper layers express WNT5A. Indeed, in human normal AC monolayer cultures rWNT5A promotes repression of anabolic genes like $A C A N$, whereas mRNA expression of catabolic genes including $M M P-1, M M P-3, M M P-13$ and $A D A M T S-4$ is enhanced [69,72]. In addition, rWNT5A induces MMP-1 and MMP-13 protein expression [69].

While WNT7A mRNA expression is downregulated in human OA AC compared to normal AC, ectopic lentiviral expression of rWNT7A in human normal AC cell cultures inhibits rIL-1 $\beta$-induced catabolic gene expression including $M M P-1, M M P-3$ and $M M P-13$, which is likely mediated via the non-canonical $\mathrm{Ca}^{2+} / \mathrm{WNT}$ signaling pathway [73].

Also, WNT3A mRNA expression is increasingly downregulated with higher grades of OA severity in human AC [74]. rWNT3A promotes dedifferentiation, indicated by loss of anabolic COL2A1 and ACAN expression in human OA AC monolayer cultures, which is mediated by the 
$\mathrm{Ca}^{2+} /$ calmodulin-dependent protein kinase 2 (CaMK2) pathway [74]. Indeed, rWNT3A-dependent induction of proliferation, but also axis inhibition protein 2 (AXIN2) expression, an inhibitor of canonical WNT signaling, is specifically mediated by the canonical WNT/ $\beta$-catenin pathway in human OA AC cells [74]. Moreover, in another study using rWNT3A in human OA AC cell monolayer cultures, activation of canonical WNT / $\beta$-catenin signaling has turned out to be a potent inhibitor of $M M P-1$, $M M P-3$, and $M M P-13$ expression and MMP activity both under basal conditions and also after rIL-1 $\beta$ stimulated NF- $\mathrm{KB}$ activation [75]. This indicates the ability of WNT3A to induce proliferation in human adult $\mathrm{AC}$, whereas catabolic gene expression is actively repressed.

Interestingly, in human OA AC mRNA and protein expression of intracellular and extracellular inhibitors of both the canonical and planar cell polarity WNT pathways (e.g., AXIN2), as well as dickkopf WNT signaling pathway inhibitor 1 and 3 (DKK1 and DKK3), are significantly upregulated compared to normal AC [70,76]. AXIN2, DKK1, and DKK3 proteins in normal human AC are predominantly localized to the SZ, whereas their expression is extended to the cells located in the deeper layers of human OA AC [70]. Yet, another study shows reduced DKK1 mRNA expression in human OA AC with increased OA grading [77]. However, despite obviously enhanced expression of canonical WNT signaling inhibitors upon onset of OA [70], increased nuclear localization of $\beta$-catenin protein occurs in human early and late $\mathrm{OA} A \mathrm{AC}$, compared to normal control $\mathrm{AC}$, indicating sustained activation of canonical WNT signaling in OA AC [78].

Human female hip and knee OA has been associated with a polymorphism in the frizzled related protein (FRZB) gene [79-81]. FRZB functions as a soluble WNT decoy receptor and, thus, can inhibit canonical and non-canonical WNT signaling pathways [82]. Interestingly, a FRZB double mutant associated with human AC OA exhibits decreased affinity for WNT molecules, suggesting a compromised ability to suppress WNT signaling [82]. In addition, decreased FRZB mRNA expression in human AC has been associated with increased OA grading [77].

Summarized, WNT signaling in human adult AC is complex. Whereas canonical WNT/ $\beta$-catenin signaling may play a proliferation-inducing and anti-catabolic role in human healthy and early OA AC, the $\mathrm{Ca}^{2+} / \mathrm{CaMK} 2$ arm of WNT signaling may induce dedifferentiation and catabolic gene expression. Progression of OA apparently depends on the balance of inhibition and activation of different WNT pathways, ultimately leading to cessation of proliferation and increased catabolism. To date, there is no evidence for a pro-inflammatory activity of WNT signaling in human AC.

\subsection{Hedgehog Signaling}

Indian hedgehog $(\mathrm{IHH})$-induced hedgehog $(\mathrm{Hh})$ signaling is a key pathway implicated in proliferation and differentiation during vertebrate AC development and longitudinal growth at the growth plate [83-85]. In human OA AC and OA SF, IHH abundance is increased compared to normal controls. Indeed, IHH protein expression is already enhanced in early human OA AC lesions and its expression increases with OA severity. In contrast, in the SF of late stage OA patients, the IHH protein content declines, compared to early OA $[86,87]$. Interestingly, the IHH protein is predominantly located in the SZ of human OA AC [86]. Additionally, in human knees categorized with the most severe $\mathrm{OA}, \mathrm{AC}$ expresses the highest levels of Hh downstream target genes glioma-associated oncogene homolog 1 (GLI1), patched 1 (PTCH1) and hedgehog interacting protein (HHIP) [88]. rIHH activates Hh signaling in human first passage monolayer cultures derived from normal adult $\mathrm{AC}$ without inducing catabolic ADAMTS-5 or MMP-13 expression. These results show that IHH signaling by itself does not cause catabolic ECM degradation in human normal AC [89]. Indeed, the lack of catabolic response to IHH signaling in healthy AC is in contrast to another study demonstrating in human OA AC explants that recombinant sonic hedgehog (SHH), another Hh ligand, induces catabolic ADAMTS-5 mRNA expression [88].

In short, the outcome of Hh signaling activation during vertebrate AC development and longitudinal bone growth has been determined in many studies. However, the impact of apparent $\mathrm{Hh}$ pathway component overexpression on human adult AC proliferation remains to be elucidated. 
In addition, the mechanistic background of Hh signaling-induced catabolic gene expression in human OA AC has to be resolved by additional research. Until today, there is no evidence for any pro-inflammatory activity of Hh signaling in human AC.

\subsection{Bone Morphogenetic Protein Signaling}

Bone morphogenetic protein (BMP) signaling, like Hh signaling, has a central function in vertebrate cartilage development, stimulating both proliferation and anabolic gene expression [90]. Also, in human adult AC BMP ligand expression can be detected. BMP-2 mRNA and protein expression is up-regulated in OA AC and OA AC derived monolayer cell cultures [91-94]. Indeed, BMP-2 mRNA expression can be detected in OA AC cell clusters and single cells of the SZ and MZ. Only in severely damaged AC, BMP-2 mRNA is also located in the DZ [92]. In primary cultures of human OA AC cells BMP-4 is upregulated compared to normal control AC cells [93]. Also, BMP-1, BMP6, and BMP-11 expression is abundant in human adult $\mathrm{AC}$, but without apparent differential regulation upon $\mathrm{OA}$ onset $[95,96]$. In contrast, BMP-3 and BMP-7 are clearly downregulated in human OA AC, although data concerning BMP-7 expression are contradictory. One study found both BMP-3 and BMP-7 predominantly expressed in the SZ of normal AC. Moreover, BMP-7 was detected in early OA AC cell clusters, whereas BMP-3 expression was absent upon OA onset [97]. In another study, both human normal and OA AC lacked BMP-7 protein expression, which was only detected in fetal, developing AC [96]. rBMP-2 induces anabolic gene expression, including ACAN and COL2A1 as well as increased proteoglycan deposition in human normal adult $\mathrm{AC}$ (both young and aged) cell cultures as well as OA AC cell cultures [91,98-101]. Expression of catabolic MMP-2 and MMP-3 mRNA is not affected by rBMP-2 [99]. Yet, another study in human OA AC monolayer cultures shows rBMP-2 induced catabolic MMP-9, MMP-13 and ADAMTS-5 mRNA expression, which is at least partially mediated by $W N T / \beta$-catenin signaling [93]. Interestingly, the proteoglycan synthesis induced by rBMP-6 in normal adult AC derived monolayer cultures shows an age dependent decrease. Also, OA AC cell cultures exhibit a limited proteoglycan deposition upon rBMP-6 comparable to aged normal AC [95]. rBMP-7 specifically promotes anabolic ACAN and COL2A1 mRNA expression in human adult OA $\mathrm{AC}$ cell high density monolayer cultures. Yet, expression of catabolic $M M P-1, M M P-3, M M P-13$ and ADAMTS-4 genes is not affected by rBMP-7 [102] or in case of human adult AC cell alginate bead cultures even reduced [100]. No positive effect of rBMP-2, rBMP-4, rBMP-6 or rBMP-7 on proliferation of human adult AC cell monolayer or alginate bead cultures was observed $[95,100]$. In addition, there is no indication that BMP signaling can promote inflammation in human OA AC, whereas rIL-1 $\beta$ and rTNF- $\alpha$ increase BMP-2 mRNA and protein levels in human OA AC explant cultures [91]. Yet, in the context of rheumatoid arthritis, BMP signaling may have anti-inflammatory functions [103].

Summarized, in human adult normal and OA AC, the outcome of BMP signaling is anabolic and potentially also catabolic, via a cross-talk with canonical WNT signaling. However, there is no evidence for a pro-proliferative or inflammation-inducing function.

\subsection{NOTCH Signaling}

In human macroscopically intact adult $\mathrm{AC}$, notch homolog $(\mathrm{NOTCH})$ receptors and ligands are scarcely expressed. However, in human OA AC mRNA and protein expression of all four NOTCH receptors, jagged 1 (JAG1) and delta-like 1 (DLL1) ligands as well as hairy and enhancer of split 1 (HES1) and HES5 are abundant, especially in cell clusters within the SZ [104-107]. Moreover, proliferation of human OA AC cell cultures in vitro is induced by and depends on active NOTCH signaling [105]. In monolayer cultures of human OA AC cells, NOTCH signaling represses the expression of BMP-2, which is implicated in anabolic gene expression. Simultaneously, the expression of pro-inflammatory and catabolic genes, including IL-8 and MMP-9, is repressed by active NOTCH signaling [105].

Taken together, NOTCH signaling appears to be activated specifically in human OA AC and to contribute to increased proliferation, whereas it likely inhibits catabolic and inflammatory gene expression. 


\subsection{Insulin-Like Growth Factor Signaling}

In normal human adult AC insulin like growth factor 1 (IGF-1) is predominantly localized in the SZ. Intriguingly, both in human OA AC and OA SF the IGF-1 protein concentration significantly increases $[108,109]$. Both in monolayer cultures and explants of human normal adult AC rIGF-1 has pro-proliferative and anabolic effects, indicated by increased proteoglycan synthesis and expression of collagen type II $[110,111]$. Interestingly, rFGF2 dose dependently antagonizes rIGF-1-mediated proteoglycan deposition in human normal AC alginate cultures, whereas both promote proliferation [112]. For human OA AC no data concerning IGF-1 signaling outcome are available.

Summarized, in human normal adult AC, IGF-1 has mitogenic and anabolic functions. Until today, IGF-1 signaling has neither been implicated in human AC catabolic gene expression nor in inflammation.

\subsection{Vascular Endothelial Growth Factor Signaling}

Angiogenesis mediated by vascular endothelial growth factor (VEGF) is a contributing factor in OA pathogenesis. Yet, angiogenesis, comprising catabolic ECM degradation and endothelial cell proliferation, remains restricted to tissues such as the synovium and the subchondral bone, whereas AC itself remains avascular during OA progression [113]. Nevertheless, VEGF A is actively expressed in human adult AC. In human normal and OA AC the mRNAs of three VEGF A isoforms (VEGF121, VEGF165, and VEGF189) can be detected and VEGF protein is predominantly localized in the SZ and MZ of OA AC, both intracellularly and in the PCM [114-116]. Intriguingly, an upregulation of VEGF expression in OA AC compared to normal adult AC has been reported [116-118]. Expression of the VEGF receptors VEGFR-1, also known as Fms related tyrosine kinase 1 (FLT-1) and VEGFR-2, also known as kinase insert domain receptor (KDR) is either restricted to OA AC compared to normal AC [115], whereas other studies reported that VEGFR-1 [116] or VEGFR-2 [119] were not detectable at all in human adult AC. Moreover, in human OA AC VEGFR-3, also known as Fms-like tyrosine kinase 4 (FLT4), is expressed in the SZ cells located in cytoplasm and on cell membrane [120]. In primary OA AC monolayer cultures catabolic MMP-1 and MMP-3 mRNA expression, but not MMP-2, MMP-9 or MMP-13 expression, can be induced by rVEGF165, whereas cultured normal AC cells exhibit no catabolic gene expression upon rVEGF165 treatment at all [115]. No proliferation-inducing effect can be attributed to rVEGF in human OA AC cells $[115,119]$.

In summary, active VEGF signaling appears to be restricted to human OA AC, where its outcome is catabolic. Yet, proliferation of human OA AC cells is not affected by VEGF. Until today, no VEGF induced expression of pro-inflammatory genes in human OA AC has been reported. Nevertheless, in other tissues pro-inflammatory VEGF action is renowned [121].

\section{Inflammatory Cytokine Signaling}

It is well-accepted that inflammation is ubiquitous during OA progression [122]. Yet, it is being debated whether inflammation may also be a primary conductive trigger for the onset of OA $[123,124]$.

IL-1 $\beta$ and TNF- $\alpha$ are the best-studied pro-inflammatory cytokines in human AC experimental OA induction [21]. Apart from that, also IL-6, the IL-6 like cytokine oncostatin M (OSM), IL-17, and IL-8 have been implicated in human OA pathogenesis $[20,125]$. Yet, IL-1 $\beta$, which has been discovered as AC destructive factor in porcine tissue, is apparently not substantially upregulated in the human SF of joints with different OA stages $[125,126]$. Moreover, in SF of OA patients the abundance of IL-1 receptor antagonist (IL-1Ra), competing with IL-1 $\beta$ for IL-1 receptor (IL-1R) binding, was 1800 times higher compared to IL-1 $\beta$ [125], whereas the IL-1R density on human OA AC cells was less than a 2-fold increased [127]. Together, these findings suggest in human OA SF in vivo an inhibition of IL-1 $\beta$ signaling at endogenous IL-1 $\beta$ concentrations [125]. 
Increased expression of IL-17a, IL-8, monokine induced by interferon-gamma (MIG) and interferon-inducible T-cell alpha chemoattractant (I-TAC) has been found in SF and serum of OA patients [128]. Another study identifies IL-6, but also IL-1 $\beta$ and TNF- $\alpha$ protein, to be specifically upregulated in serum of OA patients [36]. Moreover, $I L-6$ mRNA expression is enhanced in human fibrillated OA AC, whereas no IL-6 signal was evident in histologically normal AC from OA patients or healthy human control AC [129]. Interestingly, this study also revealed that IL-1 $\beta$ expression in human AC did not to correlate with the presence or grading of OA, whereas another study reported decreased IL-1 $\beta$ protein abundance in human OA AC with increased OA grading [130].

rIL-1 $\beta$ stimulates the expression of MMP-1, MMP-3, and MMP-13 mRNA and protein in human healthy and OA AC monolayer cultures [42,131]. In addition, rIL-1 induces IL-8 release from human OA AC cells [132]. Also, IL-6 and FGF2 mRNA expression are markedly enhanced by rIL-1 $\beta$ in human healthy AC cell cultures [131]. Indeed, rIL-17 is able to induce IL-8, IL-1 $\beta$ and IL-6 protein release in human healthy and OA AC cells [132,133]. In addition, rIL-8 upregulates secretion of IL-1 $\beta$, IL-6, TNF- $\alpha$, MMP-1, MMP-3, and MMP-13 by human OA AC cells [128]. Interestingly, in human OA AC cell cultures depletion of IL- 6 prevents rIL- $1 \beta$-induced MMP-13 expression [134], underlining the possibility that IL-1 $\beta$ may not be the primary cytokine involved in OA AC inflammation. Although human healthy and OA SF contains about $20 \mathrm{pg} / \mathrm{mL}$ IL-1 $\beta$ and less than $3 \mathrm{ng} / \mathrm{mL}$ TNF- $\alpha$, many studies using inflammatory cytokines for experimental OA induction apply apparently supra-physiological doses of $1-100 \mathrm{ng} / \mathrm{mL}$ rLL-1 $\beta$ and up to $50 \mathrm{ng} / \mathrm{mL}$ rTNF- $\alpha$ for activation of downstream signaling $[21,125]$, which may probably not reflect the natural OA pathogenesis in vivo [21].

In human AC, the signaling cascades originating from IL- $1 \beta$ and TNF- $\alpha$ converge on MAPK and NF- $\kappa B$ signaling [135] (see Figure 2). NF- $\mathrm{KB}$ in cooperation with ERK, p38 and JNK regulate rIL-1 $\beta$ and rTNF- $\alpha$-dependent catabolic MMP-13 production in human OA AC cells via E74-like factor 3 (ELF3) and activator protein 1 (AP-1) [136-138]. Knockdown of NF- $\mathrm{kB}$ p65/RelA suppresses the expression of basal and rIL-1 $\beta$-induced MMP-1 and MMP-13 mRNA in human OA AC cells [75].

Notably, IL-17 activates ERK, JNK and p38 as well as NF-KB in normal human AC cells to induce $I L-1 \beta$ and $I L-6$ expression [133]. Intriguingly, in human OA AC cells, rIL-17 activates FBJ murine osteosarcoma viral oncogene homolog B (FOSB) (AP-1 subunit), whereas IL-1 $\beta$ activates cellular oncogene Fos (cFOS) (AP-1 subunit) to induce MMP-13 release, indicating a different fine tuning of downstream signaling depending on the cytokine [139]. In addition, rIL-8 activates NF- $\mathrm{kB}$ and JNK signaling in human OA AC cells to induce IL-1 $\beta$, IL-6, TNF- $\alpha$, MMP-1, MMP-3, and MMP-13 secretion [128].

Overall, there is an intense crosstalk of inflammatory cytokine signaling with different growth factor-induced signaling pathways.

Interestingly, in human OA AC, rIL-1 $\beta$ treatment simultaneously down-regulates mRNA expression of the WNT signaling inhibitors $F R Z B$ and DKK1, whereas WNT5A mRNA expression is increased by rIL-1 $\beta$ treatment both in human healthy and OA AC. While FRZB downregulation and WNT5A overexpression have also been observed in OA patients, data for DKK1 expression in OA patients are contentious [70,77]. In human OA AC cells canonical WNT/ $\beta$-catenin signaling, activated by rWNT3A, counteracts NF-KB-mediated MMP expression induced by rIL-1 $\beta$. Additionally, rWNT3A inhibits rIL-1 $\beta$ induced IL-6 expression [75], indicating an attenuating role of canonical WNT signaling on human AC inflammation.

Both rTNF- $\alpha$ and rIL-1 $\beta$ significantly repress mRNA expression of several NOTCH pathway components, including NOTCH1, NOTCH3, JAG1, and HES5 in human healthy and OA AC cells in vitro [105]. Intriguingly, these proteins have been shown to be upregulated in human OA AC in vivo $[104,105]$, revealing the absence of inflammatory cytokine-mediated suppression of NOTCH signaling at least during early $\mathrm{OA}$ in vivo.

Hh pathway activation is suppressed by addition of rIL-1 $\beta$ in adult bovine AC explants. Conversely, rIHH weakly suppresses rIL-1 $\beta$-induced ADAMTS-5 expression in this model [89], 
indicating a negative feedback of both pathways. In healthy human AC cell alginate bead cultures rIGF-1 upregulates IL-1RII protein expression, a decoy receptor for IL-1, which may override catabolic IL-1 $\beta$ actions in healthy AC [140].

Remarkably, FGF2 is the only growth factor considered, which directly promotes the mRNA expression of $T N F-\alpha, I L-1 \beta, I L-6, I L-8$, and $M C P-1$ in human healthy AC cells, thereby promoting inflammation after 5 days of monolayer culture [32]. On the other hand, in healthy human AC and in the murine teratocarcinoma ATDC5 cell line, rIL-1 $\beta$ increases FGF2 mRNA and protein expression [32,141], indicating a potential feedback loop between FGF2 and Il-1ß.

As discussed, proliferation-induced changes in the SCSO of human AC and formation of cell clusters are early OA marker $[10,14]$. Increased expression of the proliferation markers cyclin D1 (CCDN1) and cyclin dependent kinase 6 (CDK6) has been observed in human OA AC compared to healthy control AC [142]. In addition to FGF2, growth factors like IGF-1, NOTCH ligands, and WNT have also been implicated in human adult AC cell proliferation $[13,74,105,112]$. In contrast, inflammatory cytokines clearly inhibit adult human AC cell proliferation. This is obvious in human OA AC for rIL-1 $\beta$, which inhibits proliferation and induces apoptosis [36], but also for rIL-8, which even suppresses proliferation [128]. Moreover, in rabbit AC rIL-6 represses proliferation [143]. Interestingly, in healthy human AC cell agarose bead cultures rIL-1 $\beta$ also represses rFGF2-induced proliferation and cluster formation; only IL-17R overexpression has been associated with increased FGF2 mRNA expression and cluster formation [144].

Summarized, inflammatory cytokines play an important role in human OA AC catabolism and inflammation, but it appears that they cannot be responsible for the observed OA AC proliferation, which is a hallmark of early OA. In contrast, OA AC proliferation can only be attributed to a variety of growth factors. Remarkably, of all growth factors discussed in this chapter, only FGF2 is able to concomitantly upregulate proliferation as well as induce catabolic and inflammatory gene expression, which may represent a so far not considered yet potentially important novel concept for onset of inflammation in human OA.

\section{MiRNA Regulation of Fibroblast Growth Factor 2, Transforming Growth Factor $\beta$ and Inflammatory Cytokine Signaling Pathways}

During the last years a myriad of publications addressing the differential regulation and effects of miRNA in human OA AC compared to normal AC have been published, which opened new insights into the intensive regulation and crosstalk of signaling pathways. This chapter focuses on those miRNAs with demonstrated regulatory effects in human OA AC, compared to normal AC, and with established targets in FGF2, inflammatory cytokine or TGF- $\beta$ signaling pathways (see Figure 2).

Concerning miR-9, most studies report an enhanced abundance in OA AC. Both miR-9 and IL-6 have been reported to be upregulated in damaged hip OA AC compared to undamaged AC areas of the same patients. Furthermore, rIL- $1 \beta$ and rIL-6 may induce miR- 9 expression in monolayer cultures of hip OA AC cells. In the same study, monocyte chemoattractant protein-induced protein 1 (MCPIP-1), a post-transcriptional repressor of IL-6 mRNA, has been established as miR-9 target [145]. In a second study, moderate upregulation of miR-9 in hip OA AC compared to age matched healthy AC has been reported [146]. Also, another group documented upregulation of miR-9 expression in both AC and bone of knee OA patients compared to healthy cartilage and bone from donors of the same age. Interestingly, miR-9 reduces basal and also rIL-1 $\beta$ induced MMP-13 protein expression in primary AC cells [147]. Yet, downregulation of miR-9 expression in human knee OA AC compared to age matched normal AC has been shown [148]. In this study, NF- $\kappa B 1$ has been established as a direct target of miR-9. In liver fibrosis, TGF- $\beta 1$ downregulates miR- 9 expression by promotor methylation, whereas TGFBR1 (ALK5) and TGFBR2 have been established as direct targets of miR-9 [149]. Therefore, miR-9 seems to fine-tune inflammatory cytokine signaling, whereas anabolic TGF- $\beta$ signaling is attenuated.

MiR-16 levels are upregulated in the plasma of knee OA patients [150]. Also knee and hip AC of OA patients exhibit increased miR-16 expression compared to healthy AC [151,152]. SMAD3 has 
been determined as a direct target of miR-16, implicating this miRNA in the switch to catabolic TGF- $\beta$ signaling [152]. Notably, FGF2 is a direct transcriptional target of miR-16 in human nasopharyngeal carcinoma cells [153], indicating additional repression of FGF2 signaling by this miRNA.

MiR-21 expression is elevated in human OA AC. Indeed, miR-21 suppresses chondrogenesis by directly targeting growth differentiation factor 5 (GDF5), whereas NF-KB signaling is induced [154]. Another direct target of miR-21 is tissue inhibitor of metalloproteinases 3 (TIMP3). In HUVEC, miR-21 dependent downregulation of TIMP3 coincided with increased MMP-2 and MMP-9 mRNA, and protein expression [155]. Interestingly, rIL-6-induced signal transducer and activator of transcription 3 (STAT3) activation has been implicated in increased miR-21 and miR-181 expression and malignant transformation of a human mammary epithelial cell line by constitutively activating NF- $\mathrm{kB}$ signaling [156]. Moreover, miR-21 has been implicated in several chronic diseases related to an aging-dependent increase of inflammation [157]. Collectively, this indicates a contribution of miR-21 to catabolic NF- $\mathrm{KB}$ signaling and MMP activation in response to inflammatory cytokines.

MiR-23a is another miRNA directly suppressing SMAD3 expression, alleviating anabolic TGF- $\beta$ signaling. Hypomethylation of the promoter region of miR-23a may contribute to its increased expression, which is observed for both, miR-23a and miR-23b in human hip and knee OA AC compared to healthy AC $[151,158]$. Yet, another study shows downregulation of miR-23a expression in human knee OA AC explant cultures upon rIL-1 $\beta$ treatment, whereas miR-23 expression and release were enhanced in synovial explants from OA patients [159]. This indicates an opposing scenario in rIL-1 $\beta$ treated ex vivo OA AC cultures compared to the in vivo observed upregulation.

Decreased abundance of miR-26a and miR-26b has been detected in human knee and hip OA AC compared to normal AC [151,160,161]. Notably, increasing body mass index (BMI) and NF-KB pathway activity in OA patients has been related to progressive miR-26a downregulation [162]. Direct targets for miR-26a and miR-26b dependent suppression are karyopherin subunit alpha 3 (KPNA3) that modulates NF-KB p65 translocation [161], high mobility group protein A1 (HMGA1), and mucosa-associated lymphoid tissue lymphoma translocation protein 1 (MALT1), which are also involved in positive regulation of NF-KB signaling and IL-6 expression [163]. Moreover, TAK1 and TGF- $\beta$ activated kinase 1 and MAP3K7 binding protein 3 (TAB3), two additional positive regulators of NF- $\mathrm{KB}$ signaling are directly targeted by miR-26b [164]. Besides, SMAD1 and SMAD4 are directly repressed by miR-26a [165]. Also, CCN2 is a target of miR-26a [166]. Therefore, miR-26 family downregulation activates NF- $\mathrm{kB}$ signaling, promotes catabolic TGF- $\beta$ signaling, and probably also interferes with FGF2 signaling.

MiR-27b, which directly targets $M M P-13$, is downregulated in human knee OA AC, compared to AC from young and healthy AC donors [167]. Hydrostatic pressure increases both miR-27a and miR-27b expression specifically in human hip OA AC monolayer cell cultures, but not in cell cultures derived from normal hip AC [168]. Remarkably, though rIL-1 $\beta$ downregulates miR-27a and miR-27b in human late stage knee OA AC explant cultures, in synovial explant cultures of patients with late stage knee OA AC an upregulation and enhanced secretion of miR-27a and miR-27b was detectable upon rIL-1 $\beta$ stimulation [159]. Long non-coding RNA-cartilage injury-related (lncRNA-CIR), which is upregulated in OA AC, acts as a sponge for miR-27, whereas miR-27 directly represses lncRNA-CIR expression [167]. In addition, in human chondrosarcoma cells, expression of miR-27b is negatively regulated by adiponectin (ADPN), an adipokine [169]. This indicates a differential expression of miR-27 family members in OA AC and synovium in response to rIL-1 $\beta$, whereas enhanced catabolic $M M P-13$ expression in may be reinforced by adipokines.

The human miR-29 family consists of three mature members, miR-29a, miR-29b, and miR-29c. Although, their targets are largely overlapping, differential regulation has been reported [170]. Indeed, upregulation of all three miR-29 members in human hip OA AC compared to normal AC has been reported, whereas serial passaging of OA AC cells in monolayer culture leads to miR-29 downregulation [171]. In addition, miR-29c is upregulated in the plasma of human knee OA patients compared to healthy controls [150]. Yet, another study documents miR-29a downregulation in human hip and knee OA AC compared to healthy AC and also shows a negative correlation of miR-29a 
expression with increasing BMI, whereas IL-1 $\beta$ abundance positively correlates with increasing BMI [151]. Interestingly, rFGF2 can increase miR-29a and miR-29b expression in first passage monolayer cultures of human knee AC [172], whereas both, NF- $\mathrm{kB}$ and SMAD3 have been implicated in repression of miR-29 family members [170]. rTGF- $\beta 1$ reduces miR-29 level in human primary OA AC cell cultures. Yet, while NF- $\mathrm{KB}$ inhibits miR-29 expression, rIL-1 $\beta$ increases miR-29a and miR-29b expression in a $\mathrm{p} 38$ MAPK dependent manner [171]. Indeed, rTNF- $\alpha$ has been identified as miR-29b suppressor in the human chondrosarcoma cell line SW1353 in another study [173]. Notably, miR-29c directly suppresses MMP-2 expression in human lung cancer cells [174]. Moreover, several collagen genes are predicted targets of the miR-29 family [175] and especially COL2A1 is repressed by miR-29b, whereas COL10A1 is lacking a binding site [176]. Additionally, the miR-29 family has been implicated in alterations of DNA methylation and stem cell exhaustion, which is observed during aging [157]. The fact that miR-29 is upregulated in human OA AC suggests a greater effect of FGF2 and inflammatory cytokine regulated MAPK signaling on miR-29 regulation than of NF- $k B$, as one would expect a miR-29 upregulation under predominating FGF2 and inflammatory cytokine regulated MAPK signaling and a miR-29 downregulation under predominating NF- $\mathrm{KB}$ activation. Especially SMAD3 is targeted by other upregulated miRNAs in human OA AC, suspending negative regulation by TGF- $\beta$ signaling. Therefore, miR-29 family members may actively contribute to catabolic ECM remodeling by promoting a collagen II/X imbalance in OA AC.

MiR-30a is upregulated in primary AC cells from knee OA patients compared to young healthy donors [177]. Also, a second family member, miR-30b is overexpressed in human hip and knee OA AC compared to healthy AC $[151,178]$. Moreover, miR-30b abundance is elevated in the plasma of human knee OA patients compared to healthy controls [150]. SRY-related HMG box-containing 9 (SOX9) is a direct target of miR-30a [177], whereas miR-30b targets the ETS-related gene (ERG) [178], both reducing anabolic mRNA expression. Yet, also ADAMTS-5 is a direct target of miR-30a [179]. Notably, rIL-1 $\beta$ represses miR-30a expression in monolayer cell cultures established from normal AC and OA AC by recruiting of AP-1 to the miR-30a promoter [179]. Therefore, in human OA AC the miR-30 family is apparently involved in inhibition of anabolic matrix deposition, whereas it is not pro-catabolic. However, the mechanism of miR-30a upregulation in OA AC remains elusive.

Both miR-33a and its host gene sterol regulatory element-binding protein 2 (SREBP-2) are upregulated primary cell cultures of human knee OA AC compared to healthy AC. Treatment of monolayer cultures of human OA AC cells with rTGF- $\beta 1$ increased expression miR-33a. MiR-33a reduced ATP-binding cassette transporter $A 1$ ( $A B C A 1)$ and apolipoprotein $A 1$ (APOA1) mRNA expression levels, which are both involved in cholesterol efflux and elevated $M M P-13$ expression levels. While $A B C A 1$ contains a miR-33 target sequence, the other effects are rather indirect. Indeed, in OA AC reverse cholesterol transport appears to be reduced [180].

Both miR-34a and miR-34b are upregulated in human knee OA AC compared to normal AC $[147,181]$. Also primary cell cultures of human knee OA AC show increased miR-34a expression compared to healthy controls [182]. In AC, miR-34a targets sirtuin 1 (SIRT1), which is involved in epigenetic gene silencing [182]. Another target is cysteine-rich angiogenic inducer 61 (CYR61), which inhibits ADAMTS-4. Indeed, upregulation of miR-34a by rIL-1 $\beta$ promotes ADAMTS-4 expression in human AC cells [181]. In human primary immortalized fibroblasts the MAPK activated transcription factor ELK1 is involved in miR-34a expression [183]. In prostate cancer cell lines, miR-34b significantly inhibits protein expression of TGF- $\beta$, TGF- $\beta R 1$ and p-SMAD3, but does not affect mRNA level indicating translational repression [184]. Additionally, miR-34 family members have been implicated in altered DNA damage response and telomere shortening associated with cellular senescence [157]. Therefore, this miRNA family promotes catabolic gene expression and contributes to global repression of TGF- $\beta$ signaling with a focus on the anabolic SMAD3 pathway.

MiR-105 is downregulated by rFGF2 in cell cultures established from human healthy knee AC. Mechanistically, the p65 subunit of NF-kB is implicated in FGF2-mediated miR-105 downregulation. RUNX2, involved in the transcription of ADAMTS-4, ADAMTS-5, ADAMTS-7 and ADAMTS-12, has 
been identified as direct target of miR-105 [172]. Moreover, SOX9 is a direct target of miR-105 in human glioma cells [185]. This indicates that miR-105 acts both anti-anabolically and anti-catabolically, whereas its compensatory effect is alleviated by its downregulation in OA.

MiR-125b, which targets ADAMTS-4, is downregulated by rFGF2 [172,186]. In human OA AC miR-125b is repressed compared to healthy AC. In addition, an age dependent decrease of miR-125b abundance in human AC has been observed [186]. This indicates an anti-catabolic role of miR-125b in $\mathrm{AC}$, which is attenuated by its downregulation during aging and onset of $\mathrm{OA}$.

MiR-126 has been reported to be upregulated in the plasma of human knee OA patients compared to healthy controls [150]. Yet, downregulation of miR-126 in healthy and OA AC samples from old patients, compared to AC from young, healthy patients has been detected in another study [187]. In HUVEC cells, the MAPK activated transcription factor avian erythroblastosis virus E26 oncogene homolog 1 (ETS1) has been implicated in miR-126 expression [188]. Though, in human glioma cells, Kirsten rat sarcoma viral oncogene homolog $(K R A S)$ has been identified as direct miR-126 target, indicating negative regulation of the ERK pathway [189]. Therefore, downregulation of miR-126 may reinforce MAPK signaling, while its upregulation may prevent over-activation depending on the context.

MiR-127 expression is reduced in knee OA AC compared to normal AC [190,191]. Increased $M M P-13$ expression upon rIL-1 $\beta$ treatment in monolayer cell cultures of human OA AC correlated with miR-127 suppression, with $M M P-13$ as a direct target of miR-127. In addition, miR-127 inhibits also MMP-1 expression in response to rIL-1 $\beta$ [190]. Collectively, with downregulation of miR-127 in OA AC, another anti-catabolic miRNA in AC is disenabled.

MiR-139 is specifically upregulated in the macroscopically degenerated areas of knee OA AC, compared to macroscopically intact appearing AC from the same patient [192]. rIL-1 $\beta$ and rIL-6 increase miR-139 level OA AC cell cultures, whereas inhibition of miR-139 markedly reduces IL-6 mRNA and protein expression. MCPIP1, a post-transcriptional repressor of $I L-6$ mRNA, is a direct target of miR-139. Beyond, ADAMTS-4 and MMP-13 mRNA expression is significantly increased by miR-139 mimic. This indicates the involvement of miR-139 in inflammatory cytokine-mediated catabolic gene expression in advanced OA.

Downregulation of miR-140 in human knee and hip OA AC compared to normal AC has been reported $[151,161,193]$. In cell cultures of knee OA AC and synovial fluid, expression of miR-140 negatively correlates with OA severity [194]. Yet, hydrostatic pressure increases miR-140 expression in human hip OA AC monolayer cell cultures [168]. MMP-13 [195] and IL-6 [196] are direct targets of miR-140. In the human rib cartilage cell line C28/I2 rIL-1 $\beta$ reduces miR-140 expression [195]. In contrast, TGF- $\beta$ signaling can induce miR-140 expression via SMAD3, whereas SMAD3 is also a target of miR-140 [197]. Summarized, the anti-catabolic miR-140 is repressed in human OA AC and this repression may be mediated by inflammatory cytokines, whereas the TGF- $\beta$-dependent miR-140 expression is alleviated by SMAD3 depletion.

MiR-145, upregulated in aged knee OA AC compared to normal AC from younger donors, can be induced by rIL-1 $\beta$ in monolayer cell cultures established from normal and OA AC, with stronger induction of miR-145 observed in OA AC cells [198]. Yet, others documented the downregulation of miR-145 in late stage OA AC, compared to early stage OA AC of the same patients [199] or normal AC [200]. Indeed, in human OA AC increased TNF- $\alpha$ levels correlated with a reduced miR-145 abundance [199]. SMAD3 is a direct target of miR-145 [198]. Also, human SOX9 is directly downregulated by miR-145 in cell cultures from human normal knee AC, while the target sequence is not conserved in murine Sox9. Notably, in human AC cell cultures miR-145 expression significantly increases from P0 to P2 concomitantly with dedifferentiation [201]. Another miR-145 target in human AC cell lines is tumor necrosis factor receptor superfamily member 11b (TNFRSF11B). TNFRSF11B downregulation originates upregulation of Collagen II, $\mathrm{V}$ and $\mathrm{X}$ and reduction of MMP-1, MMP-8 and MMP-13 proteins [200]. Moreover, A disintegrin and metalloproteinase domain-containing protein 17 (ADAM17) can be directly targeted by miR-145 [202], which initiates a negative feedback loop involving the ADAM17 substrate TNF- $\alpha$, which is upregulated and subsequently reduces miR-145 expression 
in renal carcinoma cell lines [203]. In human adipocytes miR-145 increases both glycerol release and TNF- $\alpha$ secretion via activation of NF- $\mathrm{KB}$ signaling [202]. Therefore, inflammatory cytokine signaling both positively and negatively interferes with miR-145 abundance, with increasing inflammation probably depleting miR-145 levels. Hence, miR-145 is involved in anti-anabolic and catabolic signaling during OA progression.

In human late stage OA AC cells miR-146a is upregulated, while during chondrogenesis of human bone MSPCs downregulation of miR-146a is observed [204]. Increased expression of miR-146a has been also detected in the plasma of human knee OA patients compared to healthy controls older than 40 years [150]. Moreover, miR-146a expression is elevated in peripheral blood mononuclear cells (PBMC) from late stage OA patients [205]. Mechanical pressure injury increases miR-146a abundance in human healthy AC cells, wherein SMAD4 has been identified as direct target of miR-146a [206]. In addition, hydrostatic pressure increases miR-146a expression in human hip OA AC monolayer cell cultures, which exhibit reduced basal miR-146a level compared normal hip AC cells [168]. However, transfection of synthetic miR-146a dose-dependently antagonized rIL-1-mediated suppression of both ACAN and COL2A1 expression in cells isolated from human early OA AC. Moreover, rIL-1 induced expression of MMP-13 and ADAMTS-5 in human early OA AC cells is significantly suppressed by miR-146a [207]. In THP-1 cells, rIL-1 $\beta$ and rTNF- $\alpha$ induce miR-146a expression mediated by NF-KB. TNF receptor-associated factor 6 (TRAF6) and IL-1 receptor-associated kinase 1 (IRAK1) have been identified as direct miR-146a target genes in these cells [208]. Interestingly, lentiviral overexpression of miR-146a increases FGF2 secretion of HUVECs by upregulation of fibroblast growth factor binding protein 1 (FGFBP1) expression via directly targeting CAMP responsive element binding protein 3 like 1 (CREB3L1) [209]. Moreover, miR-146a has been implicated in several chronic diseases related to aging dependent increase of inflammation [157]. Therefore, miR-146a is apparently fine-tuning inflammatory cytokine, TGF- $\beta$ and FGF2 signaling to prevent over-activation of inflammatory and catabolic pathways in advanced OA.

MiR-149 is significantly downregulated in human knee OA AC and micropellet cultures from OA AC, compared to normal AC. Yet, in bone it is concurrently upregulated $[147,210]$. In the chondrosarcoma cell line SW1353 both rIL-1 $\beta$ and rTNF- $\alpha$ reduce miR-149 abundance, whereas IL-6, IL-1 $\beta$ and TNF- $\alpha$ are direct targets of miR-149 [173]. Therefore, inflammatory cytokine mediated downregulation of miR-149 appears to be a self-reinforcing system to promote inflammation in advanced OA.

MiR-181a expression is increased in monolayer cell cultures isolated from aged OA AC compared to cells from aged healthy AC. Yet, specifically in cells derived from OA AC hydrostatic pressure downregulates miR-181 [211]. In human knee AC cell monolayer cultures transfection with miR-181 mimic decreases proliferation and increases apoptosis. Moreover, activity of MMP-2 and MMP-9 is enhanced by miR-181 mimic [212]. In addition, elevated miR-181a expression is associated with successful chondrogenesis of human MSPCs [213]. However, there are also studies showing a decreased expression of miR-181 family members, including miR-181a, in OA AC cell monolayer cultures, compared to healthy AC cells from younger donors [191,214]. Notably, in acute myeloid leukemia (AML) cells KRAS, neuroblastoma RAS viral oncogene homolog (NRAS) and ERK2 have been identified as direct targets of miR-181a [215]. STAT3, activated by inflammatory cytokine signaling, activates miR-181b in human MCF10A cells [216]. Apparently, the miR-181 family promotes catabolic gene expression, while repressing ERK MAPK signaling.

MiR-186 is upregulated in the plasma of human knee OA patients, compared to healthy controls [150]. In human AC, no direct regulation or transcriptional targets have been identified to date. Remarkably, in human THP-1 macrophages miR-186 enhances secretion of IL-6, IL-1 $\beta$ and TNF- $\alpha$ as well as lipid accumulation via targeting cystathionine- $\gamma$-lyase (CSE) [217]. Moreover, in human glioblastoma cells FGF2 and the NF- $\kappa B$ subunit RelA have been identified as miR-186 targets [218]. Summarized, despite induction of inflammatory cytokine expression by miR-186, the inflammatory response is apparently attenuated via NF- $\mathrm{kB}$ depletion. 
MiR-210 expression is downregulated in human knee and hip OA AC compared to normal AC $[151,219]$. Transfection of a miR-210 precursor in human OA AC derived monolayer cell cultures induces COL2A1 mRNA expression, whereas COL10A1 and MMP-13 expression is significantly reduced [219]. In human cervical cancer cells, SMAD4 has been identified as a direct target of miR-210 [220]. Hypoxia-inducible factor- $1 \alpha$ (HIF-1 $\alpha$ ) can induce miR-210 expression in various human cell lines [221]. Notably, in synovial fibroblasts from OA patients rCCN2 induces VEGF secretion by raising miR-210 expression which involves phosphatidylinositol 3-kinase (PI3K)-AKT, ERK, and NF- KB/ELK1 signaling [222]. This indicates that miR-210-mediated anabolic and anti-catabolic signaling is alleviated in human OA AC, whereas in OA synovium miR-210 acts a pro-angiogenic factor.

In human knee OA AC, miR-221 expression is downregulated with an increasing Mankin score. rIL-1 $\beta$ reduces miR-221 expression in monolayer cultures of human OA AC cells. Stromal cell derived factor 1 (SDF1), also known as C-X-C Motif Chemokine Ligand 12 (CXCL12), has been determined as direct target of miR-221 [223]. Moreover, miR-221 is downregulated in synovial fibroblasts derived from patients with OA of the temporomandibular joint (TMJ), compared to synovial fibroblasts of healthy donors. In addition, treatment with rIL-1 $\beta$ suppresses miR-221 expression in TMJ OA synovial fibroblasts. ETS1, a transcription factor involved in MMP-1, MMP-2 and MMP-9 expression, has been identified as direct miR-221 target in TMJ OA synovial fibroblasts [224]. Interestingly, increasing BMI has also been linked to reduced miR-221 abundance [225]. Therefore, reduction of miR-221 abundance by inflammatory cytokines may reinforce their catabolic target gene expression, which, in addition, appears augmented by obesity.

MiR-365 is upregulated in human late stage knee OA AC, compared to macroscopically intact cartilage from the same patients. In cell cultures established from macroscopically normal OA AC, both cyclic loading and rIL-1 $\beta$ increase miR-365 expression by a mechanism involving NF-KB. Yet, hydrostatic pressure reduces miR-365 expression in human hip OA AC monolayer cell cultures [168]. Histone deacetylase 4 (HDAC4) is a direct target of miR-365 and its downregulation has been implicated in catabolic MMP-13 and COL10A1 expression [226]. Interestingly, also IL-6 is a direct target of miR-365 [227]. Therefore, miR-365 is involved in catabolic gene expression, but its inflammatory cytokine induced overexpression may also alleviate inflammatory gene expression in a feedback loop.

Expression of miR-411 is reduced in human knee OA AC compared with normal AC. rIL-1 $\beta$ represses miR-411 in the human immortalized juvenile costal chondrocyte cell line C28/I2. Moreover, MMP-13 has been identified as direct target of miR-411 and overexpression of miR-411 mimic increases both COL2A1 and COL4A2 at mRNA and protein level [228]. This indicates an anabolic and anti-catabolic function of miR-411, which is apparently overridden by inflammatory cytokines.

Upregulation of miR-483 has been observed in human knee and hip OA AC, compared to normal AC [151,229]. Also, OA AC micropellet cultures have higher miR-483 level, compared to normal AC micropellet cultures [210]. TGF- $\beta 1$ is downregulated by overexpression of miR- 483 mimic in monolayer cultures from human normal knee AC, which coincides with COL2A1 and ACAN mRNA depletion and RUNX2 and MMP13 upregulation [230]. In human MSPC miR-483 directly targets SMAD4, which suppresses chondrogenesis. In mice, matrilin 3 (Matn3) and Timp2 have been identified as direct miR-483 targets [229]. Summarized, miR-483 negatively regulates TGF- $\beta$ signaling and apparently acts anti-anabolic and pro-catabolic in OA AC.

In monolayer cell cultures derived from human knee OA AC miR-488 expression is reduced, compared to normal AC cell cultures [231]. Exposure to rIL- $1 \beta$ reduces and rTGF- $\beta 3$ increases miR-488 abundance in normal AC cell cultures. Thereby, miR-488 inhibits MMP-13 activity through targeting the zinc-ion transporter Zrt- and Irt-like protein 8 (ZIP8) [231]. Interestingly, ZIP8 expression can be induced through the canonical NF-KB pathway, which is activated in response to several inflammatory cytokines. Increased intracellular zinc level activate metal regulatory transcription factor-1 (Mtf-1), which positively regulates Mmp-3, Mmp-9, Mmp-13, and Adamts-5 mRNA and protein expression in murine AC monolayer cell cultures [232]. In short, miR-488 obviously exerts its anti-catabolic function 
by reduction of intracellular zinc availability. Yet, its inflammatory cytokine-mediated downregulation permits catabolic gene expression and MMP activity.

This chapter summarizes the current evidence concerning 27 miRNAs, respectively miRNA families, with a significant up- or downregulation in human OA AC, compared to normal AC. As illustrated in Figure 2, differentially regulated miRNAs interfere with inflammatory cytokine, FGF2 and TGF- $\beta$ downstream signaling, which, additionally, exhibit an intense crosstalk at the protein level. In human OA AC expression of pro-catabolic target genes is mediated by NF- $\mathrm{B}$, MAPK and SMAD signaling, whereas pro-inflammatory targets are activated downstream of MAPK and NF- $\mathrm{KB}$ signaling. Though proliferation prevails during early OA, expression of catabolic ECM degrading proteins is concomitantly induced. Advanced stages of OA are characterized by sustained activation of inflammatory cytokine signaling, whereas proliferation ceases. Regarding the here discussed miRNAs, there is primarily a net upregulation of IL-6, whereas both positive and negative regulation of NF- $\mathrm{kB}$ signaling is reported. Moreover, in human OA AC upregulation of CCN2 and significantly enhanced activation of ERK, JNK and p38 MAPK pathways has been documented. Yet, evidence for ERK signaling regulation by miRNAs is contradictory. In contrast, TGF- $\beta$ signaling is globally downregulated as a consequence of miRNA presence, especially with a negative regulation of the anabolic SMAD3-mediated pathway, both on protein and miRNA level. In addition, at miRNA level, particularly a reversal of negative regulation of MMP-13 is present in OA AC, which might be also due to many studies specifically examining MMP-13, since several other MMPs are upregulated at protein level, whereas no miRNA-dependent regulation has been examined to date.

\section{Conclusions}

This review focused on the following question: which of the three key events in early OA AC-proliferation, ECM degradation, and inflammation - are inducible by growth factor signaling, inflammatory cytokine signaling, and/or miRNA regulation. Additionally, we aimed to reveal in which sequence(s) these processes can and cannot occur, and whether we can identify a single factor that is able to induce all of these key processes, according to the currently available knowledge. In this context, it is relevant to summarize that differentiated chondrocytes in the SZ of human normal adult AC are predominantly arranged in string patterns embedded in the PCM $[12,13]$ (see Figure 1). Here, growth factors including TGF- $\beta$, BMP, and IGF signaling effects mediate AC maintenance-associated anabolic PCM component deposition. However, a hallmark of early OA is proliferation of cartilage-inherent cells $[10,13,14]$, during which the cellular organization changes from single strings to double strings and eventually to small cell clusters [12,233]. During this proliferative phase, the PCM is progressively degraded, apparently by MMPs and other catabolic factors [13]. The proliferating cells may be either dedifferentiated chondrocytes reentering cell cycle or resident or immigrated MSPCs [12,13,23,233]. Whether the proliferation in OA AC is associated with an attempt of cartilage intrinsic anabolic repair or rather a prerequisite for macroscopic cartilage degradation due to a simultaneously lack of extracellular matrix (ECM) maintenance, respectively proliferation-associated degradation, remains elusive. As discussed, proliferation in early OA AC is obviously dependent on FGF2, TGF- $\beta$, WNT and NOTCH signaling $[13,63,74,105]$, whereas catabolic gene expression may be induced by FGF2, a switch in TGF- $\beta$ signaling, and inflammatory cytokines including IL-6 $[30,39,60,134]$. Importantly, according to what is known, inflammatory cytokines do not induce but in fact suppress human AC cell proliferation $[36,128]$, which in turn means that the proliferative phase during early OA is probably not inducible by inflammatory cytokines and occurs prior to inflammation, whereas catabolic ECM degradation is already apparent during the proliferative phase but steadily increasing with OA severity. Thus, the specific sequence of OA key events is described best by a very early phase of proliferation of human articular cartilage (AC) cells and concomitant anabolic/catabolic effects that are accompanied by incipient pro-inflammatory effects.

Remarkably, it was highly interesting to ask the question whether it was possible to identify any cytokine or growth factor that is potentially able to induce or reinforce all three key events promoting 
early OA onset and progression. In detail, in human OA AC, proliferation and anabolism, but also catabolism, are associated with TGF- $\beta$ effects, depending on the receptor utilization. Proliferation and anti-catabolism are associated with canonical WNT/ $\beta$-catenin signaling effects, whereas non-canonical WNT signaling may contribute to catabolic gene expression. In normal adult AC, proliferation and anabolism are associated with IGF-1 effects. NOTCH signaling contributes to proliferation in human $\mathrm{OA} \mathrm{AC}$, whereas it likely inhibits catabolic and inflammatory gene expression. BMP signaling outcome in human AC is anabolic and via a cross-talk with WNT signaling potentially also catabolic. For Hh signaling there are only very few data for human adult AC available. Yet, a potential catabolic role may be assumed. Catabolism is also associated with VEGF signaling in human OA AC. Neither for BMP nor for VEGF experimental evidence reveals a pro-proliferative effect in human AC. In human AC, both catabolism and reinforced pro-inflammatory effects are associated with inflammatory cytokines; yet, proliferation is demonstrably inhibited. Interestingly, based on currently available data, proliferation, catabolism, and pro-inflammatory effects in human AC are solely associated with FGF2. Thus, many factors are able to induce one or two of these three events examined but, importantly, FGF2 was identified as a unique factor capable of concomitantly inducing all three key events. FGF2 is not only involved in proliferative and catabolic gene expression but also in the mRNA expression of the inflammatory cytokines TNF- $\alpha, I L-1 \beta, I L-6, I L-8$, and MCP-1 [32]. Thus, FGF2-promoted MAPK and NF- $\mathrm{KB}$ signaling appears to be uniquely able to induce self-reinforcing inflammation in human adult AC, which is a hallmark of late OA. Therefore, FGF2 is the only cytokine that we can implicate in both the proliferative aspect seen in early OA and also in the degradative and inflammatory progression of later OA. According to the reviewed literature, these properties appear unique to FGF2, as this role cannot be assumed by any other growth factor or inflammatory cytokine.

This review focused on growth factor-, inflammatory cytokine-, or differential miRNA expression-induced signaling effects in the context of human primary osteoarthritis. However, it is important to mention that AC degeneration due to acute injury or due to long-standing mechanical problems such as anterior cruciate rupture or laxity, meniscal damage, and/or joint malalignment is known to lead to post-traumatic osteoarthritis (PTOA). Many differences between OA and PTOA are known; we refer to the PTOA literature $[234,235]$. The here discussed data have not been derived from studies that had PTOA in mind; e.g., models of mechanical overload such as those described in $[236,237]$, or studied therapeutic options after AC injury [238-240]. Thus, it remains unclear whether the here derived insights are valid under conditions known to lead to PTOA and designated studies using standardized injury models are needed.

Another important point is that the here discussed signaling effects should not be viewed as isolated events in AC, as several adjacent tissues, including meniscal fibrocartilage, synovium, fat, and bone, with each tissue having its own genetic propensity for anabolic, catabolic, or pro-inflammatory responses, may affect AC by secreted factors. Nevertheless, we focused in this review solely on human AC to produce a systematic foundation for events occurring in human AC, to which the other tissues; e.g., as cytokine and miRNA molecule sources may also contribute.

Collectively, the here presented view represents a novel molecular concept to interpret early OA signaling. However, designated experimental evidence is needed for its confirmation and for judging its potential value in developing novel therapeutic or preventive avenues.

Author Contributions: K.A.B. and B.R. wrote the initial manuscript and edited it until it reached its current form.

Funding: This research was funded by the VolkswagenStiftung, grant number 92701, and by the Deutsche Arthrose-Hilfe, grant number P346-A825-Rolauffs-EP1.

Acknowledgments: The article processing charge was funded by the German Research Foundation (DFG) and the University of Freiburg in the funding programme Open Access Publishing.

Conflicts of Interest: The authors declare no conflict of interest. 


\section{Abbreviations}

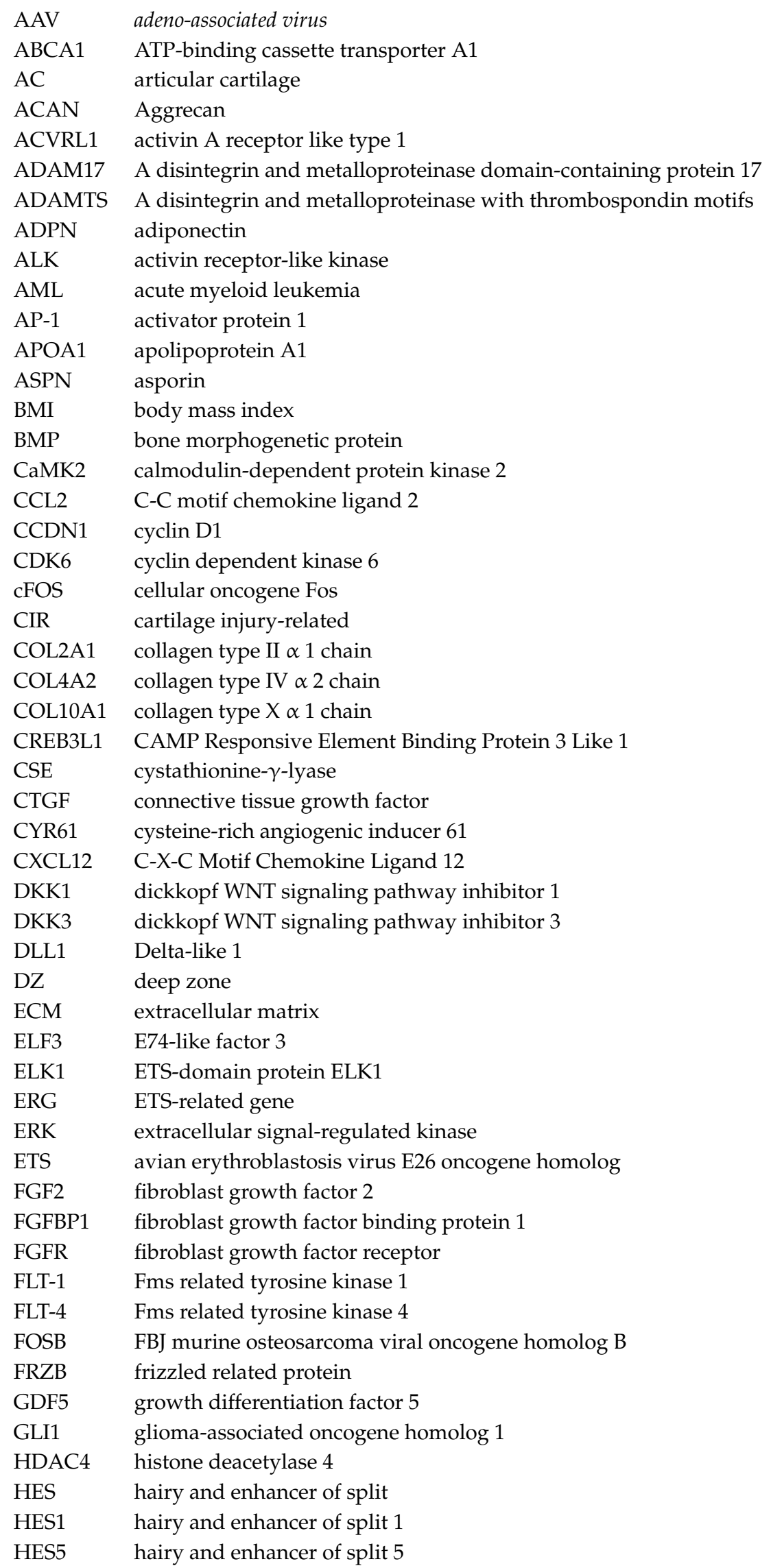




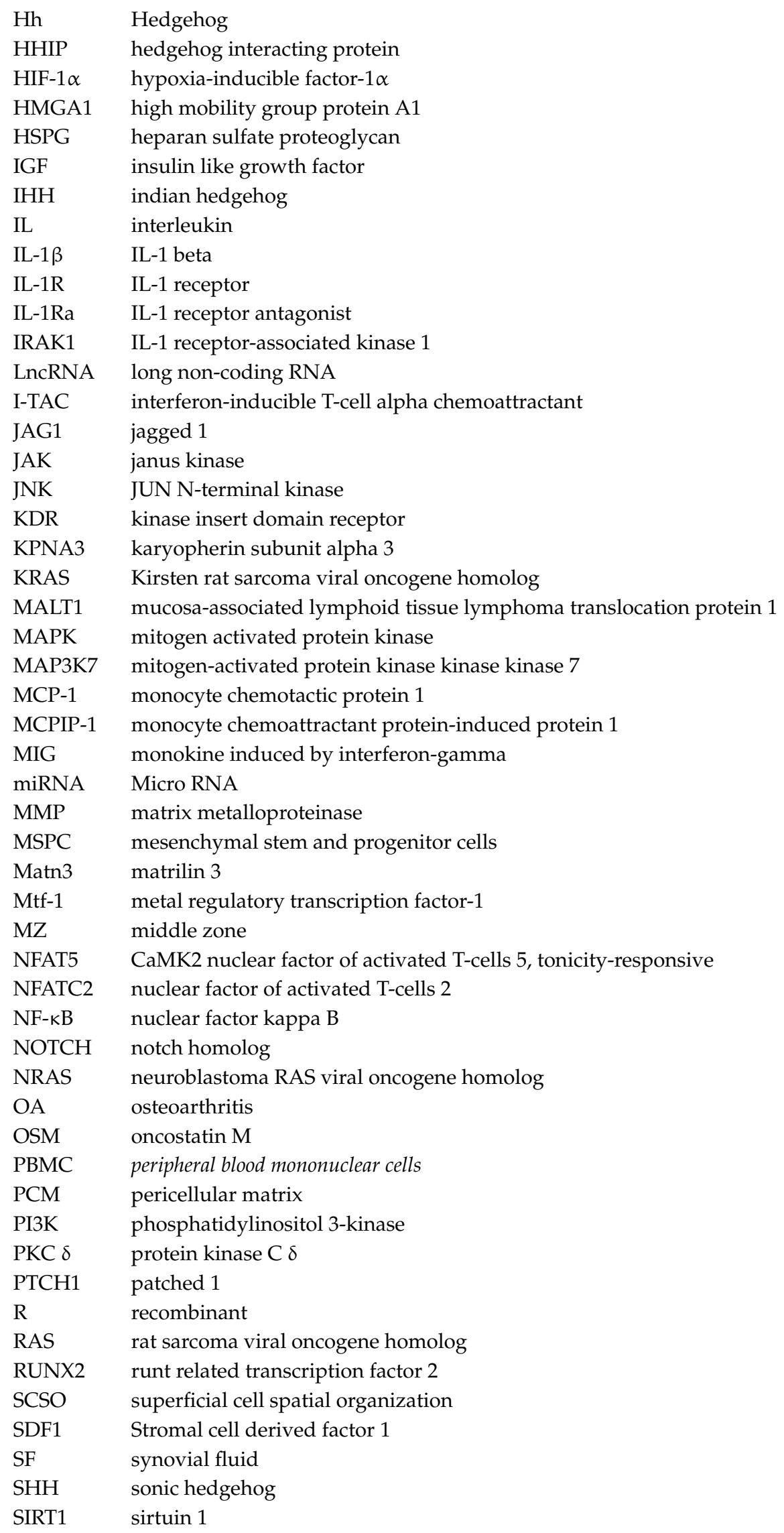




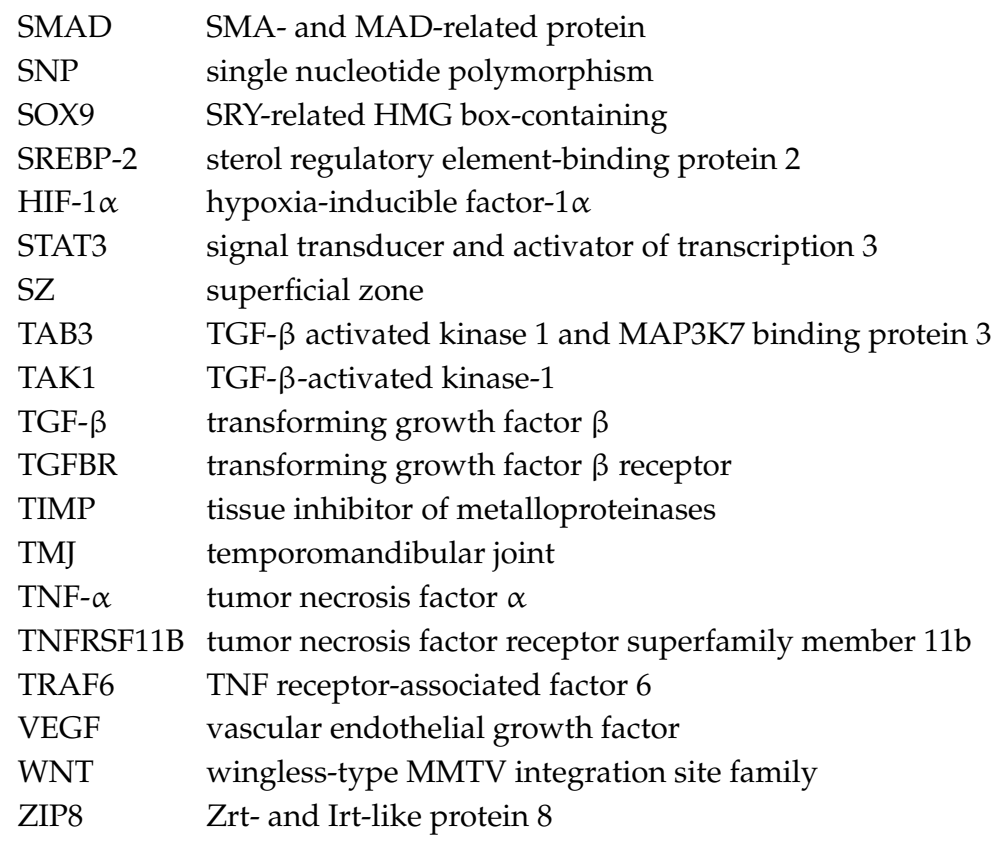

\section{References}

1. McAlindon, T.E.; Bannuru, R.R.; Sullivan, M.C.; Arden, N.K.; Berenbaum, F.; Bierma-Zeinstra, S.M.; Hawker, G.A.; Henrotin, Y.; Hunter, D.J.; Kawaguchi, H.; et al. Oarsi guidelines for the non-surgical management of knee osteoarthritis. Osteoarthr. Cartil. 2014, 22, 363-388. [CrossRef] [PubMed]

2. Ondresik, M.; Azevedo Maia, F.R.; da Silva Morais, A.; Gertrudes, A.C.; Dias Bacelar, A.H.; Correia, C.; Goncalves, C.; Radhouani, H.; Amandi Sousa, R.; Oliveira, J.M.; et al. Management of knee osteoarthritis. Current status and future trends. Biotechnol. Bioeng. 2017, 114, 717-739. [CrossRef] [PubMed]

3. Murphy, N.J.; Eyles, J.P.; Hunter, D.J. Hip osteoarthritis: Etiopathogenesis and implications for management. Adv. Ther. 2016, 33, 1921-1946. [CrossRef] [PubMed]

4. Chevalier, X.; Eymard, F.; Richette, P. Biologic agents in osteoarthritis: Hopes and disappointments. Nat. Rev. Rheumatol. 2013, 9, 400-410. [CrossRef] [PubMed]

5. Chu, C.R.; Williams, A.A.; Coyle, C.H.; Bowers, M.E. Early diagnosis to enable early treatment of pre-osteoarthritis. Arthritis Res. Ther. 2012, 14, 212. [CrossRef] [PubMed]

6. Mobasheri, A. The future of osteoarthritis therapeutics: Targeted pharmacological therapy. Curr. Rheumatol. Rep. 2013, 15, 364. [CrossRef] [PubMed]

7. Marles, P.J.; Hoyland, J.A.; Parkinson, R.; Freemont, A.J. Demonstration of variation in chondrocyte activity in different zones of articular cartilage: An assessment of the value of in-situ hybridization. Int. J. Exp. Pathol. 1991, 72, 171-182. [PubMed]

8. Asari, A.; Miyauchi, S.; Kuriyama, S.; Machida, A.; Kohno, K.; Uchiyama, Y. Localization of hyaluronic acid in human articular cartilage. J. Histochem. Cytochem. 1994, 42, 513-522. [CrossRef] [PubMed]

9. Kuettner, K.E.; Aydelotte, M.B.; Thonar, E.J. Articular cartilage matrix and structure: A minireview. J. Rheumatol. Suppl. 1991, 27, 46-48. [PubMed]

10. Aicher, W.K.; Rolauffs, B. The spatial organisation of joint surface chondrocytes: Review of its potential roles in tissue functioning, disease and early, preclinical diagnosis of osteoarthritis. Ann. Rheum. Dis. 2014, 73, 645-653. [CrossRef] [PubMed]

11. Rolauffs, B.; Williams, J.M.; Grodzinsky, A.J.; Kuettner, K.E.; Cole, A.A. Distinct horizontal patterns in the spatial organization of superficial zone chondrocytes of human joints. J. Struct. Biol. 2008, 162, 335-344. [CrossRef] [PubMed]

12. Rolauffs, B.; Williams, J.M.; Aurich, M.; Grodzinsky, A.J.; Kuettner, K.E.; Cole, A.A. Proliferative remodeling of the spatial organization of human superficial chondrocytes distant from focal early osteoarthritis. Arthritis Rheumtol. 2010, 62, 489-498. 
13. Felka, T.; Rothdiener, M.; Bast, S.; Uynuk-Ool, T.; Zouhair, S.; Ochs, B.G.; De Zwart, P.; Stoeckle, U.; Aicher, W.K.; Hart, M.L.; et al. Loss of spatial organization and destruction of the pericellular matrix in early osteoarthritis in vivo and in a novel in vitro methodology. Osteoarthr. Cartil. 2016, 24, 1200-1209. [CrossRef] [PubMed]

14. Lotz, M.K.; Otsuki, S.; Grogan, S.P.; Sah, R.; Terkeltaub, R.; D'Lima, D. Cartilage cell clusters. Arthritis Rheumtol. 2010, 62, 2206-2218. [CrossRef] [PubMed]

15. Goldring, M.B. The role of the chondrocyte in osteoarthritis. Arthritis Rheumtol. 2000, 43, $1916-1926$. [CrossRef]

16. Schumacher, B.L.; Su, J.L.; Lindley, K.M.; Kuettner, K.E.; Cole, A.A. Horizontally oriented clusters of multiple chondrons in the superficial zone of ankle, but not knee articular cartilage. Anat. Rec. 2002, 266, 241-248. [CrossRef] [PubMed]

17. Tetlow, L.C.; Adlam, D.J.; Woolley, D.E. Matrix metalloproteinase and proinflammatory cytokine production by chondrocytes of human osteoarthritic cartilage: Associations with degenerative changes. Arthritis Rheumtol. 2001, 44, 585-594. [CrossRef]

18. Bush, J.R.; Beier, F. TGF-beta and osteoarthritis-The good and the bad. Nat. Med. 2013, 19, 667-669. [CrossRef] [PubMed]

19. Bertrand, J.; Cromme, C.; Umlauf, D.; Frank, S.; Pap, T. Molecular mechanisms of cartilage remodelling in osteoarthritis. Int. J. Biochem. Cell Biol. 2010, 42, 1594-1601. [CrossRef] [PubMed]

20. Kapoor, M.; Martel-Pelletier, J.; Lajeunesse, D.; Pelletier, J.P.; Fahmi, H. Role of proinflammatory cytokines in the pathophysiology of osteoarthritis. Nat. Rev. Rheumatol. 2011, 7, 33-42. [CrossRef] [PubMed]

21. Johnson, C.I.; Argyle, D.J.; Clements, D.N. In vitro models for the study of osteoarthritis. Vet. J. 2016, 209, 40-49. [CrossRef] [PubMed]

22. Yun, Y.R.; Won, J.E.; Jeon, E.; Lee, S.; Kang, W.; Jo, H.; Jang, J.H.; Shin, U.S.; Kim, H.W. Fibroblast growth factors: Biology, function, and application for tissue regeneration. J. Tissue Eng. 2010, 2010, 218142. [CrossRef] [PubMed]

23. Boehme, K.A.; Schleicher, S.B.; Traub, F.; Rolauffs, B. Chondrosarcoma: A rare misfortune in aging human cartilage? The role of stem and progenitor cells in proliferation, malignant degeneration and therapeutic resistance. Int. J. Mol. Sci. 2018, 19, 311. [CrossRef] [PubMed]

24. Zhai, G.; Dore, J.; Rahman, P. TGF-beta signal transduction pathways and osteoarthritis. Rheumatol. Int. 2015, 35, 1283-1292. [CrossRef] [PubMed]

25. Vincent, T.L.; McLean, C.J.; Full, L.E.; Peston, D.; Saklatvala, J. FGF-2 is bound to perlecan in the pericellular matrix of articular cartilage, where it acts as a chondrocyte mechanotransducer. Osteoarthr. Cartil. 2007, 15, 752-763. [CrossRef] [PubMed]

26. Vincent, T.; Hermansson, M.; Bolton, M.; Wait, R.; Saklatvala, J. Basic fgf mediates an immediate response of articular cartilage to mechanical injury. Proc. Natl. Acad. Sci. USA 2002, 99, 8259-8264. [CrossRef] [PubMed]

27. Cucchiarini, M.; Terwilliger, E.F.; Kohn, D.; Madry, H. Remodelling of human osteoarthritic cartilage by FGF-2, alone or combined with SOX9 via RAAV gene transfer. J. Cell. Mol. Med. 2009, 13, 2476-2488. [CrossRef] [PubMed]

28. Presta, M.; Andres, G.; Leali, D.; Dell'Era, P.; Ronca, R. Inflammatory cells and chemokines sustain FGF2-induced angiogenesis. Eur. Cytokine Netw. 2009, 20, 39-50. [PubMed]

29. Honsawek, S.; Yuktanandana, P.; Tanavalee, A.; Saetan, N.; Anomasiri, W.; Parkpian, V. Correlation between plasma and synovial fluid basic fibroblast growth factor with radiographic severity in primary knee osteoarthritis. Int. Orthop. 2012, 36, 981-985. [CrossRef] [PubMed]

30. Yan, D.; Chen, D.; Cool, S.M.; van Wijnen, A.J.; Mikecz, K.; Murphy, G.; Im, H.J. Fibroblast growth factor receptor 1 is principally responsible for fibroblast growth factor 2-induced catabolic activities in human articular chondrocytes. Arthritis Res. Ther. 2011, 13, R130. [CrossRef] [PubMed]

31. Li, X.; Ellman, M.B.; Kroin, J.S.; Chen, D.; Yan, D.; Mikecz, K.; Ranjan, K.C.; Xiao, G.; Stein, G.S.; Kim, S.G.; et al. Species-specific biological effects of FGF-2 in articular cartilage: Implication for distinct roles within the fgf receptor family. J. Cell. Biochem. 2012, 113, 2532-2542. [CrossRef] [PubMed]

32. Im, H.J.; Muddasani, P.; Natarajan, V.; Schmid, T.M.; Block, J.A.; Davis, F.; van Wijnen, A.J.; Loeser, R.F. Basic fibroblast growth factor stimulates matrix metalloproteinase-13 via the molecular cross-talk between the mitogen-activated protein kinases and protein kinase cdelta pathways in human adult articular chondrocytes. J. Biol. Chem. 2007, 282, 11110-11121. [CrossRef] [PubMed] 
33. Yan, D.; Chen, D.; Im, H.J. Fibroblast growth factor-2 promotes catabolism via FGFR1-Ras-Raf-MEK1/2-ERK1/2 axis that coordinates with the PKCdelta pathway in human articular chondrocytes. J. Cell. Biochem. 2012, 113, 2856-2865. [CrossRef] [PubMed]

34. Ellman, M.B.; Yan, D.; Ahmadinia, K.; Chen, D.; An, H.S.; Im, H.J. Fibroblast growth factor control of cartilage homeostasis. J. Cell. Biochem. 2013, 114, 735-742. [CrossRef] [PubMed]

35. Muddasani, P.; Norman, J.C.; Ellman, M.; van Wijnen, A.J.; Im, H.J. Basic fibroblast growth factor activates the MAPK and NFkappaB pathways that converge on Elk-1 to control production of matrix metalloproteinase-13 by human adult articular chondrocytes. J. Biol. Chem. 2007, 282, 31409-31421. [CrossRef] [PubMed]

36. Sun, H.Y.; Hu, K.Z.; Yin, Z.S. Inhibition of the p38-mapk signaling pathway suppresses the apoptosis and expression of proinflammatory cytokines in human osteoarthritis chondrocytes. Cytokine 2016, 90, 135-143. [CrossRef] [PubMed]

37. Takebe, K.; Nishiyama, T.; Hayashi, S.; Hashimoto, S.; Fujishiro, T.; Kanzaki, N.; Kawakita, K.; Iwasa, K.; Kuroda, R.; Kurosaka, M. Regulation of p38 MAPK phosphorylation inhibits chondrocyte apoptosis in response to heat stress or mechanical stress. Int. J. Mol. Med. 2011, 27, 329-335. [PubMed]

38. Fan, Z.; Soder, S.; Oehler, S.; Fundel, K.; Aigner, T. Activation of interleukin-1 signaling cascades in normal and osteoarthritic articular cartilage. Am. J. Pathol. 2007, 171, 938-946. [CrossRef] [PubMed]

39. Nummenmaa, E.; Hamalainen, M.; Moilanen, T.; Vuolteenaho, K.; Moilanen, E. Effects of FGF-2 and FGF receptor antagonists on mmp enzymes, aggrecan, and type II collagen in primary human OA chondrocytes. Scand. J. Rheumatol. 2015, 44, 321-330. [CrossRef] [PubMed]

40. Liu, J.F.; Crepin, M.; Liu, J.M.; Barritault, D.; Ledoux, D. FGF-2 and TPA induce matrix metalloproteinase-9 secretion in MCF-7 cells through PKC activation of the RAS/ERK pathway. Biochem. Biophys. Res. Commun. 2002, 293, 1174-1182. [CrossRef]

41. Nishida, T.; Kubota, S.; Aoyama, E.; Janune, D.; Maeda, A.; Takigawa, M. Effect of CCN2 on FGF2-induced proliferation and MMP9 and MMP13 productions by chondrocytes. Endocrinology 2011, 152, 4232-4241. [CrossRef] [PubMed]

42. Wang, X.; Manner, P.A.; Horner, A.; Shum, L.; Tuan, R.S.; Nuckolls, G.H. Regulation of MMP-13 expression by RUNX2 and FGF2 in osteoarthritic cartilage. Osteoarthr. Cartil. 2004, 12, 963-973. [CrossRef] [PubMed]

43. Kamekura, S.; Kawasaki, Y.; Hoshi, K.; Shimoaka, T.; Chikuda, H.; Maruyama, Z.; Komori, T.; Sato, S.; Takeda, S.; Karsenty, G.; et al. Contribution of runt-related transcription factor 2 to the pathogenesis of osteoarthritis in mice after induction of knee joint instability. Arthritis Rheumtol. 2006, 54, 2462-2470. [CrossRef] [PubMed]

44. Kim, B.G.; Kim, H.J.; Park, H.J.; Kim, Y.J.; Yoon, W.J.; Lee, S.J.; Ryoo, H.M.; Cho, J.Y. RUNX2 phosphorylation induced by fibroblast growth factor-2/protein kinase c pathways. Proteomics 2006, 6, 1166-1174. [CrossRef] [PubMed]

45. Tetsunaga, T.; Nishida, K.; Furumatsu, T.; Naruse, K.; Hirohata, S.; Yoshida, A.; Saito, T.; Ozaki, T. Regulation of mechanical stress-induced MMP-13 and ADAMTS- 5 expression by RUNX-2 transcriptional factor in SW1353 chondrocyte-like cells. Osteoarthr. Cartil. 2011, 19, 222-232. [CrossRef] [PubMed]

46. Wang, X.; Song, Y.; Jacobi, J.L.; Tuan, R.S. Inhibition of histone deacetylases antagonized FGF2 and IL-1beta effects on MMP expression in human articular chondrocytes. Growth Factors 2009, 27, 40-49. [CrossRef] [PubMed]

47. Chia, S.L.; Sawaji, Y.; Burleigh, A.; McLean, C.; Inglis, J.; Saklatvala, J.; Vincent, T. Fibroblast growth factor 2 is an intrinsic chondroprotective agent that suppresses ADAMTS- 5 and delays cartilage degradation in murine osteoarthritis. Arthritis Rheumtol. 2009, 60, 2019-2027. [CrossRef] [PubMed]

48. Yamamoto, T.; Wakitani, S.; Imoto, K.; Hattori, T.; Nakaya, H.; Saito, M.; Yonenobu, K. Fibroblast growth factor-2 promotes the repair of partial thickness defects of articular cartilage in immature rabbits but not in mature rabbits. Osteoarthr. Cartil. 2004, 12, 636-641. [CrossRef] [PubMed]

49. Sah, R.L.; Chen, A.C.; Grodzinsky, A.J.; Trippel, S.B. Differential effects of bFGF and IGF-I on matrix metabolism in calf and adult bovine cartilage explants. Arch. Biochem. Biophys. 1994, 308, 137-147. [CrossRef] [PubMed]

50. Komatsu, M.; Nakamura, Y.; Maruyama, M.; Abe, K.; Watanapokasin, R.; Kato, H. Expression profiles of human CCN genes in patients with osteoarthritis or rheumatoid arthritis. J. Orthop. Sci. 2015, 20, 708-716. [CrossRef] [PubMed] 
51. Omoto, S.; Nishida, K.; Yamaai, Y.; Shibahara, M.; Nishida, T.; Doi, T.; Asahara, H.; Nakanishi, T.; Inoue, H.; Takigawa, M. Expression and localization of connective tissue growth factor (CTGF/Hcs24/CCN2) in osteoarthritic cartilage. Osteoarthr. Cartil. 2004, 12, 771-778. [CrossRef] [PubMed]

52. Verdier, M.P.; Seite, S.; Guntzer, K.; Pujol, J.P.; Boumediene, K. Immunohistochemical analysis of transforming growth factor beta isoforms and their receptors in human cartilage from normal and osteoarthritic femoral heads. Rheumatol. Int. 2005, 25, 118-124. [CrossRef] [PubMed]

53. Pombo-Suarez, M.; Castano-Oreja, M.T.; Calaza, M.; Gomez-Reino, J.; Gonzalez, A. Differential upregulation of the three transforming growth factor beta isoforms in human osteoarthritic cartilage. Ann. Rheum. Dis. 2009, 68, 568-571. [CrossRef] [PubMed]

54. Wu, J.; Liu, W.; Bemis, A.; Wang, E.; Qiu, Y.; Morris, E.A.; Flannery, C.R.; Yang, Z. Comparative proteomic characterization of articular cartilage tissue from normal donors and patients with osteoarthritis. Arthritis Rheumtol. 2007, 56, 3675-3684. [CrossRef] [PubMed]

55. Kizawa, H.; Kou, I.; Iida, A.; Sudo, A.; Miyamoto, Y.; Fukuda, A.; Mabuchi, A.; Kotani, A.; Kawakami, A.; Yamamoto, S.; et al. An aspartic acid repeat polymorphism in asporin inhibits chondrogenesis and increases susceptibility to osteoarthritis. Nat. Genet. 2005, 37, 138-144. [CrossRef] [PubMed]

56. Nakajima, M.; Kizawa, H.; Saitoh, M.; Kou, I.; Miyazono, K.; Ikegawa, S. Mechanisms for asporin function and regulation in articular cartilage. J. Biol. Chem. 2007, 282, 32185-32192. [CrossRef] [PubMed]

57. Valdes, A.M.; Spector, T.D.; Tamm, A.; Kisand, K.; Doherty, S.A.; Dennison, E.M.; Mangino, M.; Tamm, A.; KeRNA, I.; Hart, D.J.; et al. Genetic variation in the SMAD3 gene is associated with hip and knee osteoarthritis. Arthritis Rheumtol. 2010, 62, 2347-2352. [CrossRef] [PubMed]

58. Guerne, P.A.; Blanco, F.; Kaelin, A.; Desgeorges, A.; Lotz, M. Growth factor responsiveness of human articular chondrocytes in aging and development. Arthritis Rheumtol. 1995, 38, 960-968. [CrossRef]

59. Yaeger, P.C.; Masi, T.L.; de Ortiz, J.L.; Binette, F.; Tubo, R.; McPherson, J.M. Synergistic action of transforming growth factor-beta and insulin-like growth factor-I induces expression of type II collagen and aggrecan genes in adult human articular chondrocytes. Exp. Cell Res. 1997, 237, 318-325. [CrossRef] [PubMed]

60. Blaney Davidson, E.N.; Remst, D.F.; Vitters, E.L.; van Beuningen, H.M.; Blom, A.B.; Goumans, M.J.; van den Berg, W.B.; van der Kraan, P.M. Increase in ALK1/ALK5 ratio as a cause for elevated MMP-13 expression in osteoarthritis in humans and mice. J. Immunol. 2009, 182, 7937-7945. [CrossRef] [PubMed]

61. Finnson, K.W.; Parker, W.L.; ten Dijke, P.; Thorikay, M.; Philip, A. ALK1 opposes ALK5/SMAD3 signaling and expression of extracellular matrix components in human chondrocytes. J. Bone Miner. Res. 2008, 23, 896-906. [CrossRef] [PubMed]

62. Van der Kraan, P.M.; Goumans, M.J.; Blaney Davidson, E.; ten Dijke, P. Age-dependent alteration of tgf-beta signalling in osteoarthritis. Cell Tissue Res. 2012, 347, 257-265. [CrossRef] [PubMed]

63. Venkatesan, J.K.; Rey-Rico, A.; Schmitt, G.; Wezel, A.; Madry, H.; Cucchiarini, M. rAAV-mediated overexpression of TGF-beta stably restructures human osteoarthritic articular cartilage in situ. J. Transl. Med. 2013, 11, 211. [CrossRef] [PubMed]

64. Blaney Davidson, E.N.; van der Kraan, P.M.; van den Berg, W.B. TGF-beta and osteoarthritis. Osteoarthr. Cartil. 2007, 15, 597-604. [CrossRef] [PubMed]

65. Finnson, K.W.; Chi, Y.; Bou-Gharios, G.; Leask, A.; Philip, A. TGF-b signaling in cartilage homeostasis and osteoarthritis. Front. Biosci. (Schol. Ed.) 2012, 4, 251-268. [CrossRef] [PubMed]

66. Nakerakanti, S.S.; Bujor, A.M.; Trojanowska, M. CCN2 is required for the TGF-beta induced activation of SMAD1-ERK1/2 signaling network. PLoS ONE 2011, 6, e21911. [CrossRef] [PubMed]

67. Tran, C.M.; Markova, D.; Smith, H.E.; Susarla, B.; Ponnappan, R.K.; Anderson, D.G.; Symes, A.; Shapiro, I.M.; Risbud, M.V. Regulation of CCN2/connective tissue growth factor expression in the nucleus pulposus of the intervertebral disc: Role of Smad and activator protein 1 signaling. Arthritis Rheumtol. 2010, 62, 1983-1992.

68. Cheng, J.; Hu, X.; Dai, L.; Zhang, X.; Ren, B.; Shi, W.; Liu, Z.; Duan, X.; Zhang, J.; Fu, X.; et al. Inhibition of transforming growth factor beta-activated kinase 1 prevents inflammation-related cartilage degradation in osteoarthritis. Sci. Rep. 2016, 6, 34497. [CrossRef] [PubMed]

69. Huang, G.; Chubinskaya, S.; Liao, W.; Loeser, R.F. Wnt5a induces catabolic signaling and matrix metalloproteinase production in human articular chondrocytes. Osteoarthr. Cartil. 2017, 25, 1505-1515. [CrossRef] [PubMed] 
70. Thorfve, A.; Dehne, T.; Lindahl, A.; Brittberg, M.; Pruss, A.; Ringe, J.; Sittinger, M.; Karlsson, C. Characteristic markers of the wnt signaling pathways are differentially expressed in osteoarthritic cartilage. Cartilage 2012, 3, 43-57. [CrossRef] [PubMed]

71. Li, Y.; Xiao, W.; Sun, M.; Deng, Z.; Zeng, C.; Li, H.; Yang, T.; Li, L.; Luo, W.; Lei, G. The expression of osteopontin and wnt5a in articular cartilage of patients with knee osteoarthritis and its correlation with disease severity. Biomed. Res. Int. 2016, 2016, 9561058. [CrossRef] [PubMed]

72. Thirunavukkarasu, K.; Pei, Y.; Moore, T.L.; Wang, H.; Yu, X.P.; Geiser, A.G.; Chandrasekhar, S. Regulation of the human adamts-4 promoter by transcription factors and cytokines. Biochem. Biophys. Res. Commun. 2006, 345, 197-204. [CrossRef] [PubMed]

73. Gibson, A.L.; Hui Mingalone, C.K.; Foote, A.T.; Uchimura, T.; Zhang, M.; Zeng, L. Wnt7a inhibits il-1beta induced catabolic gene expression and prevents articular cartilage damage in experimental osteoarthritis. Sci. Rep. 2017, 7, 41823. [CrossRef] [PubMed]

74. Nalesso, G.; Sherwood, J.; Bertrand, J.; Pap, T.; Ramachandran, M.; De Bari, C.; Pitzalis, C.; Dell'accio, F. Wnt-3a modulates articular chondrocyte phenotype by activating both canonical and noncanonical pathways. J. Cell. Biol. 2011, 193, 551-564. [CrossRef] [PubMed]

75. Ma, B.; van Blitterswijk, C.A.; Karperien, M. A Wnt/beta-catenin negative feedback loop inhibits interleukin-1-induced matrix metalloproteinase expression in human articular chondrocytes. Arthritis Rheumtol. 2012, 64, 2589-2600. [CrossRef] [PubMed]

76. Snelling, S.J.; Davidson, R.K.; Swingler, T.E.; Le, L.T.; Barter, M.J.; Culley, K.L.; Price, A.; Carr, A.J.; Clark, I.M. Dickkopf-3 is upregulated in osteoarthritis and has a chondroprotective role. Osteoarthr. Cartil. 2016, 24, 883-891. [CrossRef] [PubMed]

77. Leijten, J.C.; Bos, S.D.; Landman, E.B.; Georgi, N.; Jahr, H.; Meulenbelt, I.; Post, J.N.; van Blitterswijk, C.A.; Karperien, M. GREM1, FRZB and DKK1 mRNA levels correlate with osteoarthritis and are regulated by osteoarthritis-associated factors. Arthritis Res. Ther. 2013, 15, R126. [CrossRef] [PubMed]

78. Zhu, M.; Tang, D.; Wu, Q.; Hao, S.; Chen, M.; Xie, C.; Rosier, R.N.; O'Keefe, R.J.; Zuscik, M.; Chen, D. Activation of beta-catenin signaling in articular chondrocytes leads to osteoarthritis-like phenotype in adult beta-catenin conditional activation mice. J. Bone Miner. Res. 2009, 24, 12-21. [CrossRef] [PubMed]

79. Min, J.L.; Meulenbelt, I.; Riyazi, N.; Kloppenburg, M.; Houwing-Duistermaat, J.J.; Seymour, A.B.; Pols, H.A.; van Duijn, C.M.; Slagboom, P.E. Association of the frizzled-related protein gene with symptomatic osteoarthritis at multiple sites. Arthritis Rheumtol. 2005, 52, 1077-1080. [CrossRef] [PubMed]

80. Loughlin, J.; Dowling, B.; Chapman, K.; Marcelline, L.; Mustafa, Z.; Southam, L.; Ferreira, A.; Ciesielski, C.; Carson, D.A.; Corr, M. Functional variants within the secreted frizzled-related protein 3 gene are associated with hip osteoarthritis in females. Proc. Natl. Acad. Sci. USA 2004, 101, 9757-9762. [CrossRef] [PubMed]

81. Valdes, A.M.; Loughlin, J.; Oene, M.V.; Chapman, K.; Surdulescu, G.L.; Doherty, M.; Spector, T.D. Sex and ethnic differences in the association of ASPN, CALM1, COL2A1, COMP, and FRZB with genetic susceptibility to osteoarthritis of the knee. Arthritis Rheumtol. 2007, 56, 137-146. [CrossRef] [PubMed]

82. Oldefest, M.; Dusterhoft, S.; Desel, C.; Thysen, S.; Fink, C.; Rabe, B.; Lories, R.; Grotzinger, J.; Lorenzen, I. Secreted frizzled-related protein 3 (sFRP3)-mediated suppression of interleukin-6 receptor release by a disintegrin and metalloprotease 17 (ADAM17) is abrogated in the osteoarthritis-associated rare double variant of sFRP3. Biochem. J. 2015, 468, 507-518. [CrossRef] [PubMed]

83. Minina, E.; Wenzel, H.M.; Kreschel, C.; Karp, S.; Gaffield, W.; McMahon, A.P.; Vortkamp, A. BMP and Ihh/PTHrP signaling interact to coordinate chondrocyte proliferation and differentiation. Development 2001, 128, 4523-4534. [PubMed]

84. Ohba, S. Hedgehog signaling in endochondral ossification. J. Dev. Biol. 2016, 4, 20. [CrossRef] [PubMed]

85. Kronenberg, H.M. PTHrP and skeletal development. Ann. N. Y. Acad. Sci. 2006, 1068, 1-13. [CrossRef] [PubMed]

86. Wei, F.; Zhou, J.; Wei, X.; Zhang, J.; Fleming, B.C.; Terek, R.; Pei, M.; Chen, Q.; Liu, T.; Wei, L. Activation of Indian hedgehog promotes chondrocyte hypertrophy and upregulation of mmp-13 in human osteoarthritic cartilage. Osteoarthr. Cartil. 2012, 20, 755-763. [CrossRef] [PubMed]

87. Zhang, C.; Wei, X.; Chen, C.; Cao, K.; Li, Y.; Jiao, Q.; Ding, J.; Zhou, J.; Fleming, B.C.; Chen, Q.; et al. Indian hedgehog in synovial fluid is a novel marker for early cartilage lesions in human knee joint. Int. J. Mol. Sci. 2014, 15, 7250-7265. [CrossRef] [PubMed] 
88. Lin, A.C.; Seeto, B.L.; Bartoszko, J.M.; Khoury, M.A.; Whetstone, H.; Ho, L.; Hsu, C.; Ali, S.A.; Alman, B.A. Modulating hedgehog signaling can attenuate the severity of osteoarthritis. Nat. Med. 2009, 15, 1421-1425. [CrossRef] [PubMed]

89. Thompson, C.L.; Patel, R.; Kelly, T.A.; Wann, A.K.; Hung, C.T.; Chapple, J.P.; Knight, M.M. Hedgehog signalling does not stimulate cartilage catabolism and is inhibited by interleukin-1beta. Arthritis Res. Ther. 2015, 17, 373. [CrossRef] [PubMed]

90. Van der Kraan, P.M.; Blaney Davidson, E.N.; van den Berg, W.B. Bone morphogenetic proteins and articular cartilage: To serve and protect or a wolf in sheep clothing's? Osteoarthr. Cartil. 2010, 18, 735-741. [CrossRef] [PubMed]

91. Fukui, N.; Zhu, Y.; Maloney, W.J.; Clohisy, J.; Sandell, L.J. Stimulation of BMP-2 expression by pro-inflammatory cytokines IL-1 and TNF-alpha in normal and osteoarthritic chondrocytes. J. Bone Jt. Surg. Am. 2003, 85-A (Suppl. 3), 59-66. [CrossRef]

92. Nakase, T.; Miyaji, T.; Tomita, T.; Kaneko, M.; Kuriyama, K.; Myoui, A.; Sugamoto, K.; Ochi, T.; Yoshikawa, H. Localization of bone morphogenetic protein-2 in human osteoarthritic cartilage and osteophyte. Osteoarthr. Cartil. 2003, 11, 278-284. [CrossRef]

93. Papathanasiou, I.; Malizos, K.N.; Tsezou, A. Bone morphogenetic protein-2-induced Wnt/beta-catenin signaling pathway activation through enhanced low-density-lipoprotein receptor-related protein 5 catabolic activity contributes to hypertrophy in osteoarthritic chondrocytes. Arthritis Res. Ther. 2012, 14, R82. [CrossRef] [PubMed]

94. Schmal, H.; Pilz, I.H.; Mehlhorn, A.T.; Dovi-Akue, D.; Kirchhoff, C.; Sudkamp, N.P.; Gerlach, U.; Niemeyer, P. Expression of BMP-receptor type 1A correlates with progress of osteoarthritis in human knee joints with focal cartilage lesions. Cytotherapy 2012, 14, 868-876. [CrossRef] [PubMed]

95. Bobacz, K.; Gruber, R.; Soleiman, A.; Erlacher, L.; Smolen, J.S.; Graninger, W.B. Expression of bone morphogenetic protein 6 in healthy and osteoarthritic human articular chondrocytes and stimulation of matrix synthesis in vitro. Arthritis Rheumtol. 2003, 48, 2501-2508. [CrossRef] [PubMed]

96. Chen, A.L.; Fang, C.; Liu, C.; Leslie, M.P.; Chang, E.; Di Cesare, P.E. Expression of bone morphogenetic proteins, receptors, and tissue inhibitors in human fetal, adult, and osteoarthritic articular cartilage. J. Orthop. Res. 2004, 22, 1188-1192. [CrossRef] [PubMed]

97. Bobinac, D.; Spanjol, J.; Marinovic, M.; Zoricic Cvek, S.; Maric, I.; Cicvaric, T.; Fuckar, D.; Markic, D.; Vojnikovic, B. Expression of bone morphogenetic proteins, cartilage-derived morphogenetic proteins and related receptors in normal and osteoarthritic human articular cartilage. Coll. Antropol. 2008, 32 (Suppl. 2), $83-87$.

98. Lafont, J.E.; Poujade, F.A.; Pasdeloup, M.; Neyret, P.; Mallein-Gerin, F. Hypoxia potentiates the bmp-2 driven COL2A1 stimulation in human articular chondrocytes via p38 MAPK. Osteoarthr. Cartil. 2016, 24, 856-867. [CrossRef] [PubMed]

99. Smith, R.L.; Lindsey, D.P.; Dhulipala, L.; Harris, A.H.; Goodman, S.B.; Maloney, W.J. Effects of intermittent hydrostatic pressure and BMP-2 on osteoarthritic human chondrocyte metabolism in vitro. J. Orthop. Res. 2011, 29, 361-368. [CrossRef] [PubMed]

100. Chubinskaya, S.; Segalite, D.; Pikovsky, D.; Hakimiyan, A.A.; Rueger, D.C. Effects induced by BMPs in cultures of human articular chondrocytes: Comparative studies. Growth Factors 2008, 26, 275-283. [CrossRef] [PubMed]

101. Murphy, M.K.; Huey, D.J.; Hu, J.C.; Athanasiou, K.A. TGF-beta1, GDF-5, and BMP-2 stimulation induces chondrogenesis in expanded human articular chondrocytes and marrow-derived stromal cells. Stem Cells 2015, 33, 762-773. [CrossRef] [PubMed]

102. Fan, Z.; Chubinskaya, S.; Rueger, D.C.; Bau, B.; Haag, J.; Aigner, T. Regulation of anabolic and catabolic gene expression in normal and osteoarthritic adult human articular chondrocytes by osteogenic protein-1. Clin. Exp. Rheumatol. 2004, 22, 103-106. [PubMed]

103. Varas, A.; Valencia, J.; Lavocat, F.; Martinez, V.G.; Thiam, N.N.; Hidalgo, L.; FeRNAndez-Sevilla, L.M.; Sacedon, R.; Vicente, A.; Miossec, P. Blockade of bone morphogenetic protein signaling potentiates the pro-inflammatory phenotype induced by interleukin-17 and tumor necrosis factor-alpha combination in rheumatoid synoviocytes. Arthritis Res. Ther. 2015, 17, 192. [CrossRef] [PubMed] 
104. Mahjoub, M.; Sassi, N.; Driss, M.; Laadhar, L.; Allouche, M.; Hamdoun, M.; Romdhane, K.B.; Sellami, S.; Makni, S. Expression patterns of notch receptors and their ligands in human osteoarthritic and healthy articular cartilage. Tissue Cell 2012, 44, 182-194. [CrossRef] [PubMed]

105. Karlsson, C.; Brantsing, C.; Egell, S.; Lindahl, A. Notch1, Jagged1, and HES5 are abundantly expressed in osteoarthritis. Cells Tissues Organs 2008, 188, 287-298. [CrossRef] [PubMed]

106. Grogan, S.P.; Miyaki, S.; Asahara, H.; D'Lima, D.D.; Lotz, M.K. Mesenchymal progenitor cell markers in human articular cartilage: Normal distribution and changes in osteoarthritis. Arthritis Res. Ther. 2009, 11, R85. [CrossRef] [PubMed]

107. Lin, N.Y.; Distler, A.; Beyer, C.; Philipi-Schobinger, A.; Breda, S.; Dees, C.; Stock, M.; Tomcik, M.; Niemeier, A.; Dell'Accio, F.; et al. Inhibition of notch1 promotes hedgehog signalling in a HES1-dependent manner in chondrocytes and exacerbates experimental osteoarthritis. Ann. Rheum. Dis. 2016, 75, 2037-2044. [CrossRef] [PubMed]

108. Schneiderman, R.; Rosenberg, N.; Hiss, J.; Lee, P.; Liu, F.; Hintz, R.L.; Maroudas, A. Concentration and size distribution of insulin-like growth factor-I in human normal and osteoarthritic synovial fluid and cartilage. Arch. Biochem. Biophys. 1995, 324, 173-188. [CrossRef] [PubMed]

109. Tavera, C.; Abribat, T.; Reboul, P.; Dore, S.; Brazeau, P.; Pelletier, J.P.; Martel-Pelletier, J. IGF and IGF-binding protein system in the synovial fluid of osteoarthritic and rheumatoid arthritic patients. Osteoarthr. Cartil. 1996, 4, 263-274. [CrossRef]

110. Starkman, B.G.; Cravero, J.D.; Delcarlo, M.; Loeser, R.F. IGF-I stimulation of proteoglycan synthesis by chondrocytes requires activation of the PI 3-kinase pathway but not ERK MAPK. Biochem. J. 2005, 389, 723-729. [CrossRef] [PubMed]

111. Weimer, A.; Madry, H.; Venkatesan, J.K.; Schmitt, G.; Frisch, J.; Wezel, A.; Jung, J.; Kohn, D.; Terwilliger, E.F.; Trippel, S.B.; et al. Benefits of recombinant adeno-associated virus (rAAV)-mediated insulinlike growth factor I (IGF-I) overexpression for the long-term reconstruction of human osteoarthritic cartilage by modulation of the IGF-I axis. Mol. Med. 2012, 18, 346-358. [CrossRef] [PubMed]

112. Loeser, R.F.; Chubinskaya, S.; Pacione, C.; Im, H.J. Basic fibroblast growth factor inhibits the anabolic activity of insulin-like growth factor 1 and osteogenic protein 1 in adult human articular chondrocytes. Arthritis Rheumtol. 2005, 52, 3910-3917. [CrossRef] [PubMed]

113. Murata, M.; Yudoh, K.; Masuko, K. The potential role of vascular endothelial growth factor (VEGF) in cartilage: How the angiogenic factor could be involved in the pathogenesis of osteoarthritis? Osteoarthr. Cartil. 2008, 16, 279-286. [CrossRef] [PubMed]

114. Fay, J.; Varoga, D.; Wruck, C.J.; Kurz, B.; Goldring, M.B.; Pufe, T. Reactive oxygen species induce expression of vascular endothelial growth factor in chondrocytes and human articular cartilage explants. Arthritis Res. Ther. 2006, 8, R189. [CrossRef] [PubMed]

115. Enomoto, H.; Inoki, I.; Komiya, K.; Shiomi, T.; Ikeda, E.; Obata, K.; Matsumoto, H.; Toyama, Y.; Okada, Y. Vascular endothelial growth factor isoforms and their receptors are expressed in human osteoarthritic cartilage. Am. J. Pathol. 2003, 162, 171-181. [CrossRef]

116. Pufe, T.; Petersen, W.; Tillmann, B.; Mentlein, R. The splice variants VEGF121 and VEGF189 of the angiogenic peptide vascular endothelial growth factor are expressed in osteoarthritic cartilage. Arthritis Rheumtol. 2001, 44, 1082-1088. [CrossRef]

117. Pfander, D.; Kortje, D.; Zimmermann, R.; Weseloh, G.; Kirsch, T.; Gesslein, M.; Cramer, T.; Swoboda, B. Vascular endothelial growth factor in articular cartilage of healthy and osteoarthritic human knee joints. Ann. Rheum. Dis. 2001, 60, 1070-1073. [CrossRef] [PubMed]

118. Su, W.; Xie, W.; Shang, Q.; Su, B. The long noncoding RNA MEG3 is downregulated and inversely associated with VEGF levels in osteoarthritis. Biomed. Res. Int. 2015, 2015, 356893. [CrossRef] [PubMed]

119. Pulsatelli, L.; Dolzani, P.; Silvestri, T.; Frizziero, L.; Facchini, A.; Meliconi, R. Vascular endothelial growth factor activities on osteoarthritic chondrocytes. Clin. Exp. Rheumatol. 2005, 23, 487-493. [PubMed]

120. Shakibaei, M.; Schulze-Tanzil, G.; Mobasheri, A.; Beichler, T.; Dressler, J.; Schwab, W. Expression of the VEGF receptor-3 in osteoarthritic chondrocytes: Stimulation by interleukin-1 beta and association with beta 1-integrins. Histochem. Cell Biol. 2003, 120, 235-241. [CrossRef] [PubMed]

121. Takahashi, H.; Shibuya, M. The vascular endothelial growth factor (VEGF)/VEGF receptor system and its role under physiological and pathological conditions. Clin. Sci. (Lond.) 2005, 109, 227-241. [CrossRef] [PubMed] 
122. Loeser, R.F.; Collins, J.A.; Diekman, B.O. Ageing and the pathogenesis of osteoarthritis. Nat. Rev. Rheumatol. 2016, 12, 412-420. [CrossRef] [PubMed]

123. Berenbaum, F. Osteoarthritis as an inflammatory disease (osteoarthritis is not osteoarthrosis!). Osteoarthr. Cartil. 2013, 21, 16-21. [CrossRef] [PubMed]

124. Sokolove, J.; Lepus, C.M. Role of inflammation in the pathogenesis of osteoarthritis: Latest findings and interpretations. Ther. Adv. Musculoskelet. Dis. 2013, 5, 77-94. [CrossRef] [PubMed]

125. Sandy, J.D.; Chan, D.D.; Trevino, R.L.; Wimmer, M.A.; Plaas, A. Human genome-wide expression analysis reorients the study of inflammatory mediators and biomechanics in osteoarthritis. Osteoarthr. Cartil. 2015, 23, 1939-1945. [CrossRef] [PubMed]

126. Kahle, P.; Saal, J.G.; Schaudt, K.; Zacher, J.; Fritz, P.; Pawelec, G. Determination of cytokines in synovial fluids: Correlation with diagnosis and histomorphological characteristics of synovial tissue. Ann. Rheum. Dis. 1992, 51, 731-734. [CrossRef] [PubMed]

127. Martel-Pelletier, J.; McCollum, R.; DiBattista, J.; Faure, M.P.; Chin, J.A.; Fournier, S.; Sarfati, M.; Pelletier, J.P. The interleukin-1 receptor in normal and osteoarthritic human articular chondrocytes. Identification as the type I receptor and analysis of binding kinetics and biologic function. Arthritis Rheumtol. 1992, 35, 530-540. [CrossRef]

128. Yang, P.; Tan, J.; Yuan, Z.; Meng, G.; Bi, L.; Liu, J. Expression profile of cytokines and chemokines in osteoarthritis patients: Proinflammatory roles for CXCL8 and CXCL11 to chondrocytes. Int. Immunopharmacol. 2016, 40, 16-23. [CrossRef] [PubMed]

129. Middleton, J.; Manthey, A.; Tyler, J. Insulin-like growth factor (IGF) receptor, IGF-i, interleukin-1 beta (IL-1 beta), and IL-6 mRNA expression in osteoarthritic and normal human cartilage. J. Histochem. Cytochem. 1996, 44, 133-141. [CrossRef] [PubMed]

130. Towle, C.A.; Hung, H.H.; Bonassar, L.J.; Treadwell, B.V.; Mangham, D.C. Detection of interleukin-1 in the cartilage of patients with osteoarthritis: A possible autocrine/paracrine role in pathogenesis. Osteoarthr. Cartil. 1997, 5, 293-300. [CrossRef]

131. Aigner, T.; McKenna, L.; Zien, A.; Fan, Z.; Gebhard, P.M.; Zimmer, R. Gene expression profiling of serumand interleukin-1 beta-stimulated primary human adult articular chondrocytes-A molecular analysis based on chondrocytes isolated from one donor. Cytokine 2005, 31, 227-240. [CrossRef] [PubMed]

132. Honorati, M.C.; Bovara, M.; Cattini, L.; Piacentini, A.; Facchini, A. Contribution of interleukin 17 to human cartilage degradation and synovial inflammation in osteoarthritis. Osteoarthr. Cartil. 2002, 10, $799-807$. [CrossRef] [PubMed]

133. Shalom-Barak, T.; Quach, J.; Lotz, M. Interleukin-17-induced gene expression in articular chondrocytes is associated with activation of mitogen-activated protein kinases and NF-kappaB. J. Biol. Chem. 1998, 273, 27467-27473. [CrossRef] [PubMed]

134. Haseeb, A.; Ansari, M.Y.; Haqqi, T.M. Harpagoside suppresses IL-6 expression in primary human osteoarthritis chondrocytes. J. Orthop. Res. 2017, 35, 311-320. [CrossRef] [PubMed]

135. Goldring, M.B.; Otero, M.; Plumb, D.A.; Dragomir, C.; Favero, M.; El Hachem, K.; Hashimoto, K.; Roach, H.I.; Olivotto, E.; Borzi, R.M.; et al. Roles of inflammatory and anabolic cytokines in cartilage metabolism: Signals and multiple effectors converge upon MMP-13 regulation in osteoarthritis. Eur. Cells Mater. 2011, 21, 202-220. [CrossRef]

136. Otero, M.; Plumb, D.A.; Tsuchimochi, K.; Dragomir, C.L.; Hashimoto, K.; Peng, H.; Olivotto, E.; Bevilacqua, M.; Tan, L.; Yang, Z.; et al. E74-like factor 3 (ELF3) impacts on matrix metalloproteinase 13 (mmp13) transcriptional control in articular chondrocytes under proinflammatory stress. J. Biol. Chem. 2012, 287, 3559-3572. [CrossRef] [PubMed]

137. Liacini, A.; Sylvester, J.; Li, W.Q.; Zafarullah, M. Inhibition of interleukin-1-stimulated MAP kinases, activating protein-1 (AP-1) and nuclear factor kappa b (NF-kappa b) transcription factors down-regulates matrix metalloproteinase gene expression in articular chondrocytes. Matrix Biol. 2002, 21, 251-262. [CrossRef]

138. Liacini, A.; Sylvester, J.; Li, W.Q.; Huang, W.; Dehnade, F.; Ahmad, M.; Zafarullah, M. Induction of matrix metalloproteinase-13 gene expression by TNF-alpha is mediated by map kinases, AP-1, and NF-kappab transcription factors in articular chondrocytes. Exp. Cell Res. 2003, 288, 208-217. [CrossRef] 
139. Benderdour, M.; Tardif, G.; Pelletier, J.P.; Di Battista, J.A.; Reboul, P.; Ranger, P.; Martel-Pelletier, J. Interleukin 17 (IL-17) induces collagenase-3 production in human osteoarthritic chondrocytes via AP-1 dependent activation: Differential activation of AP-1 members by IL-17 and IL-1beta. J. Rheumatol. 2002, 29, 1262-1272. [PubMed]

140. Wang, J.; Elewaut, D.; Veys, E.M.; Verbruggen, G. Insulin-like growth factor 1-induced interleukin-1 receptor ii overrides the activity of interleukin- 1 and controls the homeostasis of the extracellular matrix of cartilage. Arthritis Rheumtol. 2003, 48, 1281-1291. [CrossRef] [PubMed]

141. Chien, S.Y.; Huang, C.Y.; Tsai, C.H.; Wang, S.W.; Lin, Y.M.; Tang, C.H. Interleukin-1beta induces fibroblast growth factor 2 expression and subsequently promotes endothelial progenitor cell angiogenesis in chondrocytes. Clin. Sci. (Lond.) 2016, 130, 667-681. [CrossRef] [PubMed]

142. De Andres, M.C.; Takahashi, A.; Oreffo, R.O. Demethylation of an NF-kappaB enhancer element orchestrates inos induction in osteoarthritis and is associated with altered chondrocyte cell cycle. Osteoarthr. Cartil. 2016, 24, 1951-1960. [CrossRef] [PubMed]

143. Jikko, A.; Wakisaka, T.; Iwamoto, M.; Hiranuma, H.; Kato, Y.; Maeda, T.; Fujishita, M.; Fuchihata, H. Effects of interleukin-6 on proliferation and proteoglycan metabolism in articular chondrocyte cultures. Cell Biol. Int. 1998, 22, 615-621. [CrossRef] [PubMed]

144. Quintavalla, J.; Kumar, C.; Daouti, S.; Slosberg, E.; Uziel-Fusi, S. Chondrocyte cluster formation in agarose cultures as a functional assay to identify genes expressed in osteoarthritis. J. Cell. Physiol. 2005, 204, 560-566. [CrossRef] [PubMed]

145. Makki, M.S.; Haseeb, A.; Haqqi, T.M. MicroRNA-9 promotion of interleukin-6 expression by inhibiting monocyte chemoattractant protein-induced protein 1 expression in interleukin-1beta-stimulated human chondrocytes. Arthritis Rheumatol. 2015, 67, 2117-2128. [CrossRef] [PubMed]

146. Kopanska, M.; Szala, D.; Czech, J.; Gablo, N.; Gargasz, K.; Trzeciak, M.; Zawlik, I.; Snela, S. MiRNA expression in the cartilage of patients with osteoarthritis. J. Orthop. Surg. Res. 2017, 12, 51. [CrossRef] [PubMed]

147. Jones, S.W.; Watkins, G.; Le Good, N.; Roberts, S.; Murphy, C.L.; Brockbank, S.M.; Needham, M.R.; Read, S.J.; Newham, P. The identification of differentially expressed microRNA in osteoarthritic tissue that modulate the production of TNF-alpha and MMP13. Osteoarthr. Cartil. 2009, 17, 464-472. [CrossRef] [PubMed]

148. Gu, R.; Liu, N.; Luo, S.; Huang, W.; Zha, Z.; Yang, J. MicroRNA-9 regulates the development of knee osteoarthritis through the NF-kappaB1 pathway in chondrocytes. Medicine (Baltimore) 2016, 95, e4315. [CrossRef] [PubMed]

149. Yu, F.; Chen, B.; Fan, X.; Li, G.; Dong, P.; Zheng, J. Epigenetically-regulated microRNA-9-5p suppresses the activation of hepatic stellate cells via TGFBR1 and TGFBR2. Cell. Physiol. Biochem. 2017, 43, 2242-2252. [CrossRef] [PubMed]

150. Borgonio Cuadra, V.M.; Gonzalez-Huerta, N.C.; Romero-Cordoba, S.; Hidalgo-Miranda, A.; Miranda-Duarte, A. Altered expression of circulating microRNA in plasma of patients with primary osteoarthritis and in silico analysis of their pathways. PLoS ONE 2014, 9, e97690. [CrossRef] [PubMed]

151. Iliopoulos, D.; Malizos, K.N.; Oikonomou, P.; Tsezou, A. Integrative microRNA and proteomic approaches identify novel osteoarthritis genes and their collaborative metabolic and inflammatory networks. PLoS ONE 2008, 3, e3740. [CrossRef] [PubMed]

152. Li, L.; Jia, J.; Liu, X.; Yang, S.; Ye, S.; Yang, W.; Zhang, Y. MicroRNA-16-5p controls development of osteoarthritis by targeting SMAD3 in chondrocytes. Curr. Pharm. Des. 2015, 21, 5160-5167. [CrossRef] [PubMed]

153. He, Q.; Ren, X.; Chen, J.; Li, Y.; Tang, X.; Wen, X.; Yang, X.; Zhang, J.; Wang, Y.; Ma, J.; et al. miR-16 targets fibroblast growth factor 2 to inhibit NPC cell proliferation and invasion via PI3K/AKT and MAPK signaling pathways. Oncotarget 2016, 7, 3047-3058. [CrossRef] [PubMed]

154. Zhang, Y.; Jia, J.; Yang, S.; Liu, X.; Ye, S.; Tian, H. MicroRNA-21 controls the development of osteoarthritis by targeting GDF-5 in chondrocytes. Exp. Mol. Med. 2014, 46, e79. [CrossRef] [PubMed]

155. Hu, J.; Ni, S.; Cao, Y.; Zhang, T.; Wu, T.; Yin, X.; Lang, Y.; Lu, H. The angiogenic effect of microRNA-21 targeting TIMP3 through the regulation of MMP2 and MMP9. PLoS ONE 2016, 11, e0149537. [CrossRef] [PubMed]

156. Iliopoulos, D.; Hirsch, H.A.; Struhl, K. An epigenetic switch involving NF-kappaB, Lin28, Let-7 microRNA, and IL6 links inflammation to cell transformation. Cell 2009, 139, 693-706. [CrossRef] [PubMed] 
157. Harries, L.W. MicroRNAs as mediators of the ageing process. Genes (Basel) 2014, 5, 656-670. [CrossRef] [PubMed]

158. Kang, L.; Yang, C.; Song, Y.; Liu, W.; Wang, K.; Li, S.; Zhang, Y. MicroRNA-23a-3p promotes the development of osteoarthritis by directly targeting smad3 in chondrocytes. Biochem. Biophys. Res. Commun. 2016, 478, 467-473. [CrossRef] [PubMed]

159. Li, Y.H.; Tavallaee, G.; Tokar, T.; Nakamura, A.; Sundararajan, K.; Weston, A.; Sharma, A.; Mahomed, N.N.; Gandhi, R.; Jurisica, I.; et al. Identification of synovial fluid microRNA signature in knee osteoarthritis: Differentiating early- and late-stage knee osteoarthritis. Osteoarthr. Cartil. 2016, 24, 1577-1586. [CrossRef] [PubMed]

160. Hu, J.; Wang, Z.; Pan, Y.; Ma, J.; Miao, X.; Qi, X.; Zhou, H.; Jia, L. miR-26a and mir-26b mediate osteoarthritis progression by targeting FUT4 via NF-kappaB signaling pathway. Int. J. Biochem. Cell Biol. 2018, 94, 79-88. [CrossRef] [PubMed]

161. Yin, X.; Wang, J.Q.; Yan, S.Y. Reduced miR26a and miR26b expression contributes to the pathogenesis of osteoarthritis via the promotion of p65 translocation. Mol. Med. Rep. 2017, 15, 551-558. [CrossRef] [PubMed]

162. Xie, Q.; Wei, M.; Kang, X.; Liu, D.; Quan, Y.; Pan, X.; Liu, X.; Liao, D.; Liu, J.; Zhang, B. Reciprocal inhibition between miR-26a and NF-kappaB regulates obesity-related chronic inflammation in chondrocytes. Biosci. Rep. 2015, 35, e00204. [CrossRef] [PubMed]

163. Chen, C.Y.; Chang, J.T.; Ho, Y.F.; Shyu, A.B. miR-26 down-regulates TNF-alpha/NF-kappaB signalling and IL-6 expression by silencing HMGA1 and MALT1. Nucleic Acids Res. 2016, 44, 3772-3787. [CrossRef] [PubMed]

164. Zhao, N.; Wang, R.; Zhou, L.; Zhu, Y.; Gong, J.; Zhuang, S.M. MicroRNA-26b suppresses the nf-kappab signaling and enhances the chemosensitivity of hepatocellular carcinoma cells by targeting TAK1 and TAB3. Mol. Cancer 2014, 13, 35. [CrossRef] [PubMed]

165. Leeper, N.J.; Raiesdana, A.; Kojima, Y.; Chun, H.J.; Azuma, J.; Maegdefessel, L.; Kundu, R.K.; Quertermous, T.; Tsao, P.S.; Spin, J.M. MicroRNA-26a is a novel regulator of vascular smooth muscle cell function. J. Cell. Physiol. 2011, 226, 1035-1043. [CrossRef] [PubMed]

166. Wei, C.; Kim, I.K.; Kumar, S.; Jayasinghe, S.; Hong, N.; Castoldi, G.; Catalucci, D.; Jones, W.K.; Gupta, S. NF-kappaB mediated mir-26a regulation in cardiac fibrosis. J. Cell. Physiol. 2013, 228, 1433-1442. [CrossRef] [PubMed]

167. Li, Y.F.; Li, S.H.; Liu, Y.; Luo, Y.T. Long noncoding RNA CIR promotes chondrocyte extracellular matrix degradation in osteoarthritis by acting as a sponge for mir-27b. Cell. Physiol. Biochem. 2017, 43, 602-610. [CrossRef] [PubMed]

168. Cheleschi, S.; De Palma, A.; Pecorelli, A.; Pascarelli, N.A.; Valacchi, G.; Belmonte, G.; Carta, S.; Galeazzi, M.; Fioravanti, A. Hydrostatic pressure regulates microRNA expression levels in osteoarthritic chondrocyte cultures via the wnt/beta-catenin pathway. Int. J. Mol. Sci. 2017, 18, 133. [CrossRef] [PubMed]

169. Huang, C.Y.; Chang, A.C.; Chen, H.T.; Wang, S.W.; Lo, Y.S.; Tang, C.H. Adiponectin promotes VEGF-C-dependent lymphangiogenesis by inhibiting mir-27b through a caMKII/AMPK/p38 signaling pathway in human chondrosarcoma cells. Clin. Sci. (Lond.) 2016, 130, 1523-1533. [CrossRef] [PubMed]

170. Kriegel, A.J.; Liu, Y.; Fang, Y.; Ding, X.; Liang, M. The mir-29 family: Genomics, cell biology, and relevance to renal and cardiovascular injury. Physiol. Genom. 2012, 44, 237-244. [CrossRef] [PubMed]

171. Le, L.T.; Swingler, T.E.; Crowe, N.; Vincent, T.L.; Barter, M.J.; Donell, S.T.; Delany, A.M.; Dalmay, T.; Young, D.A.; Clark, I.M. The microRNA-29 family in cartilage homeostasis and osteoarthritis. J. Mol. Med. (Berl.) 2016, 94, 583-596. [CrossRef] [PubMed]

172. Ji, Q.; Xu, X.; Xu, Y.; Fan, Z.; Kang, L.; Li, L.; Liang, Y.; Guo, J.; Hong, T.; Li, Z.; et al. miR-105/Runx2 axis mediates FGF2-induced ADAMTS expression in osteoarthritis cartilage. J. Mol. Med. (Berl.) 2016, 94, 681-694. [CrossRef] [PubMed]

173. Santini, P.; Politi, L.; Vedova, P.D.; Scandurra, R.; Scotto d'Abusco, A. The inflammatory circuitry of mir-149 as a pathological mechanism in osteoarthritis. Rheumatol. Int. 2014, 34, 711-716. [CrossRef] [PubMed]

174. Wang, H.; Zhu, Y.; Zhao, M.; Wu, C.; Zhang, P.; Tang, L.; Zhang, H.; Chen, X.; Yang, Y.; Liu, G. miRNA-29c suppresses lung cancer cell adhesion to extracellular matrix and metastasis by targeting integrin beta1 and matrix metalloproteinase2 (MMP2). PLoS ONE 2013, 8, e70192. 
175. Liu, Y.; Taylor, N.E.; Lu, L.; Usa, K.; Cowley, A.W., Jr.; Ferreri, N.R.; Yeo, N.C.; Liang, M. Renal medullary microRNAs in dahl salt-sensitive rats: Mir-29b regulates several collagens and related genes. Hypertension 2010, 55, 974-982. [CrossRef] [PubMed]

176. Moulin, D.; Salone, V.; Koufany, M.; Clement, T.; Behm-Ansmant, I.; Branlant, C.; Charpentier, B.; Jouzeau, J.Y. MicroRNA-29b contributes to collagens imbalance in human osteoarthritic and dedifferentiated articular chondrocytes. BioMed Res. Int. 2017, 2017, 9792512. [CrossRef] [PubMed]

177. Chang, T.; Xie, J.; Li, H.; Li, D.; Liu, P.; Hu, Y. MicroRNA-30a promotes extracellular matrix degradation in articular cartilage via downregulation of Sox9. Cell Prolif. 2016, 49, 207-218. [CrossRef] [PubMed]

178. Li, L.; Yang, C.; Liu, X.; Yang, S.; Ye, S.; Jia, J.; Liu, W.; Zhang, Y. Elevated expression of microRNA-30b in osteoarthritis and its role in erg regulation of chondrocyte. Biomed. Pharmacother. 2015, 76, 94-99. [CrossRef] [PubMed]

179. Ji, Q.; Xu, X.; Zhang, Q.; Kang, L.; Xu, Y.; Zhang, K.; Li, L.; Liang, Y.; Hong, T.; Ye, Q.; et al. The IL-1beta/AP-1/miR-30a/ADAMTS-5 axis regulates cartilage matrix degradation in human osteoarthritis. J. Mol. Med. (Berl.) 2016, 94, 771-785. [CrossRef] [PubMed]

180. Kostopoulou, F.; Malizos, K.N.; Papathanasiou, I.; Tsezou, A. MicroRNA-33a regulates cholesterol synthesis and cholesterol efflux-related genes in osteoarthritic chondrocytes. Arthritis Res. Ther. 2015, 17, 42. [CrossRef] [PubMed]

181. Yang, B.; Ni, J.; Long, H.; Huang, J.; Yang, C.; Huang, X. IL-1beta-induced miR-34a up-regulation inhibits cyr61 to modulate osteoarthritis chondrocyte proliferation through ADAMTS-4. J. Cell. Biochem. 2017. [CrossRef]

182. Yan, S.; Wang, M.; Zhao, J.; Zhang, H.; Zhou, C.; Jin, L.; Zhang, Y.; Qiu, X.; Ma, B.; Fan, Q. MicroRNA-34a affects chondrocyte apoptosis and proliferation by targeting the sirt1/p53 signaling pathway during the pathogenesis of osteoarthritis. Int. J. Mol. Med. 2016, 38, 201-209. [CrossRef] [PubMed]

183. Christoffersen, N.R.; Shalgi, R.; Frankel, L.B.; Leucci, E.; Lees, M.; Klausen, M.; Pilpel, Y.; Nielsen, F.C.; Oren, M.; Lund, A.H. P53-independent upregulation of mir-34a during oncogene-induced senescence represses myc. Cell Death Differ. 2010, 17, 236-245. [CrossRef] [PubMed]

184. Fang, L.L.; Sun, B.F.; Huang, L.R.; Yuan, H.B.; Zhang, S.; Chen, J.; Yu, Z.J.; Luo, H. Potent inhibition of mir-34b on migration and invasion in metastatic prostate cancer cells by regulating the TGF-beta pathway. Int. J. Mol. Sci. 2017, 18, 2762. [CrossRef] [PubMed]

185. Liu, X.; Wang, H.; Zhu, Z.; Ye, Y.; Mao, H.; Zhang, S. MicroRNA-105 targets SOX9 and inhibits human glioma cell progression. FEBS Lett. 2016, 590, 4329-4342. [CrossRef] [PubMed]

186. Matsukawa, T.; Sakai, T.; Yonezawa, T.; Hiraiwa, H.; Hamada, T.; Nakashima, M.; Ono, Y.; Ishizuka, S.; Nakahara, H.; Lotz, M.K.; et al. MicroRNA-125b regulates the expression of aggrecanase-1 (ADAMTS-4) in human osteoarthritic chondrocytes. Arthritis Res. Ther. 2013, 15, R28. [CrossRef] [PubMed]

187. Balaskas, P.; Goljanek-Whysall, K.; Clegg, P.; Fang, Y.; Cremers, A.; Emans, P.; Welting, T.; Peffers, M. MicroRNA profiling in cartilage ageing. Int. J. Genom. 2017, 2017, 2713725. [CrossRef] [PubMed]

188. Li, P.; Wei, J.; Li, X.; Cheng, Y.; Chen, W.; Cui, Y.; Simoncini, T.; Gu, Z.; Yang, J.; Fu, X. 17beta-estradiol enhances vascular endothelial Ets-1/miR-126-3p expression: The possible mechanism for attenuation of atherosclerosis. J. Clin. Endocrinol. Metab. 2017, 102, 594-603. [PubMed]

189. Li, Y.; Li, Y.; Ge, P.; Ma, C. Mir-126 regulates the ERK pathway via targeting KRAS to inhibit the glioma cell proliferation and invasion. Mol. Neurobiol. 2017, 54, 137-145. [CrossRef] [PubMed]

190. Park, S.J.; Cheon, E.J.; Lee, M.H.; Kim, H.A. MicroRNA-127-5p regulates matrix metalloproteinase 13 expression and interleukin-1beta-induced catabolic effects in human chondrocytes. Arthritis Rheumtol. 2013, 65, 3141-3152. [CrossRef] [PubMed]

191. Tu, M.; Li, Y.; Zeng, C.; Deng, Z.; Gao, S.; Xiao, W.; Luo, W.; Jiang, W.; Li, L.; Lei, G. MicroRNA-127-5p regulates osteopontin expression and osteopontin-mediated proliferation of human chondrocytes. Sci. Rep. 2016, 6, 25032. [CrossRef] [PubMed]

192. Makki, M.S.; Haqqi, T.M. Mir-139 modulates mcpip1/IL-6 expression and induces apoptosis in human OA chondrocytes. Exp. Mol. Med. 2015, 47, e189. [CrossRef] [PubMed]

193. Miyaki, S.; Nakasa, T.; Otsuki, S.; Grogan, S.P.; Higashiyama, R.; Inoue, A.; Kato, Y.; Sato, T.; Lotz, M.K.; Asahara, H. MicroRNA-140 is expressed in differentiated human articular chondrocytes and modulates interleukin-1 responses. Arthritis Rheumtol. 2009, 60, 2723-2730. [CrossRef] [PubMed] 
194. Si, H.; Zeng, Y.; Zhou, Z.; Pei, F.; Lu, Y.; Cheng, J.; Shen, B. Expression of miRNA-140 in chondrocytes and synovial fluid of knee joints in patients with osteoarthritis. Chin. Med. Sci. J. 2016, 31, 207-212. [CrossRef]

195. Liang, Z.J.; Zhuang, H.; Wang, G.X.; Li, Z.; Zhang, H.T.; Yu, T.Q.; Zhang, B.D. MiRNA-140 is a negative feedback regulator of MMP-13 in IL-1beta-stimulated human articular chondrocyte c28/i2 cells. Inflamm. Res. 2012, 61, 503-509. [CrossRef] [PubMed]

196. Yoshida, A.; Kitajima, S.; Li, F.; Cheng, C.; Takegami, Y.; Kohno, S.; Wan, Y.S.; Hayashi, N.; Muranaka, H.; Nishimoto, Y.; et al. MicroRNA-140 mediates RB tumor suppressor function to control stem cell-like activity through interleukin-6. Oncotarget 2017, 8, 13872-13885. [CrossRef] [PubMed]

197. Tardif, G.; Pelletier, J.P.; Fahmi, H.; Hum, D.; Zhang, Y.; Kapoor, M.; Martel-Pelletier, J. Nfat3 and TGF-beta/smad3 regulate the expression of mir-140 in osteoarthritis. Arthritis Res. Ther. 2013, 15, R197. [CrossRef] [PubMed]

198. Yang, B.; Kang, X.; Xing, Y.; Dou, C.; Kang, F.; Li, J.; Quan, Y.; Dong, S. Effect of microRNA-145 on il-1beta-induced cartilage degradation in human chondrocytes. FEBS Lett. 2014, 588, 2344-2352. [CrossRef] [PubMed]

199. Hu, G.; Zhao, X.; Wang, C.; Geng, Y.; Zhao, J.; Xu, J.; Zuo, B.; Zhao, C.; Wang, C.; Zhang, X. MicroRNA-145 attenuates TNF-alpha-driven cartilage matrix degradation in osteoarthritis via direct suppression of mkk4. Cell Death Dis. 2017, 8, e3140. [CrossRef] [PubMed]

200. Wang, G.D.; Zhao, X.W.; Zhang, Y.G.; Kong, Y.; Niu, S.S.; Ma, L.F.; Zhang, Y.M. Effects of mir-145 on the inhibition of chondrocyte proliferation and fibrosis by targeting tnfrsf $11 \mathrm{~b}$ in human osteoarthritis. Mol. Med. Rep. 2017, 15, 75-80. [CrossRef] [PubMed]

201. Martinez-Sanchez, A.; Dudek, K.A.; Murphy, C.L. Regulation of human chondrocyte function through direct inhibition of cartilage master regulator SOX9 by microRNA-145 (miRNA-145). J. Biol. Chem. 2012, 287, 916-924. [CrossRef] [PubMed]

202. Lorente-Cebrian, S.; Mejhert, N.; Kulyte, A.; Laurencikiene, J.; Astrom, G.; Heden, P.; Ryden, M.; Arner, P. MicroRNAs regulate human adipocyte lipolysis: Effects of mir-145 are linked to TNF-alpha. PLoS ONE 2014, 9, e86800. [CrossRef] [PubMed]

203. Doberstein, K.; Steinmeyer, N.; Hartmetz, A.K.; Eberhardt, W.; Mittelbronn, M.; Harter, P.N.; Juengel, E.; Blaheta, R.; Pfeilschifter, J.; Gutwein, P. MicroRNA-145 targets the metalloprotease ADAM17 and is suppressed in renal cell carcinoma patients. Neoplasia 2013, 15, 218-230. [CrossRef] [PubMed]

204. Budd, E.; de Andres, M.C.; Sanchez-Elsner, T.; Oreffo, R.O.C. Mir-146b is down-regulated during the chondrogenic differentiation of human bone marrow derived skeletal stem cells and up-regulated in osteoarthritis. Sci. Rep. 2017, 7, 46704. [CrossRef] [PubMed]

205. Soyocak, A.; Kurt, H.; Ozgen, M.; Turgut Cosan, D.; Colak, E.; Gunes, H.V. MiRNA-146a, miRNA-155 and jnk expression levels in peripheral blood mononuclear cells according to grade of knee osteoarthritis. Gene 2017, 627, 207-211. [CrossRef] [PubMed]

206. Jin, L.; Zhao, J.; Jing, W.; Yan, S.; Wang, X.; Xiao, C.; Ma, B. Role of miR-146a in human chondrocyte apoptosis in response to mechanical pressure injury in vitro. Int. J. Mol. Med. 2014, 34, 451-463. [CrossRef] [PubMed]

207. Li, X.; Gibson, G.; Kim, J.S.; Kroin, J.; Xu, S.; van Wijnen, A.J.; Im, H.J. MicroRNA-146a is linked to pain-related pathophysiology of osteoarthritis. Gene 2011, 480, 34-41. [CrossRef] [PubMed]

208. Taganov, K.D.; Boldin, M.P.; Chang, K.J.; Baltimore, D. NF-kappaB-dependent induction of microRNA miR-146, an inhibitor targeted to signaling proteins of innate immune responses. Proc. Natl. Acad. Sci. USA 2006, 103, 12481-12486. [CrossRef] [PubMed]

209. Zhu, H.Y.; Bai, W.D.; Liu, J.Q.; Zheng, Z.; Guan, H.; Zhou, Q.; Su, L.L.; Xie, S.T.; Wang, Y.C.; Li, J.; et al. Up-regulation of FGFBP1 signaling contributes to mir-146a-induced angiogenesis in human umbilical vein endothelial cells. Sci. Rep. 2016, 6, 25272. [CrossRef] [PubMed]

210. Diaz-Prado, S.; Cicione, C.; Muinos-Lopez, E.; Hermida-Gomez, T.; Oreiro, N.; FeRNAndez-Lopez, C.; Blanco, F.J. Characterization of microRNA expression profiles in normal and osteoarthritic human chondrocytes. BMC Musculoskelet. Disord. 2012, 13, 144. [CrossRef] [PubMed]

211. De Palma, A.; Cheleschi, S.; Pascarelli, N.A.; Giannotti, S.; Galeazzi, M.; Fioravanti, A. Hydrostatic pressure as epigenetic modulator in chondrocyte cultures: A study on miRNA-155, miRNA-181a and miRNA-223 expression levels. J. Biomech. 2018, 66, 165-169. [CrossRef] [PubMed]

212. Wu, X.F.; Zhou, Z.H.; Zou, J. MicroRNA-181 inhibits proliferation and promotes apoptosis of chondrocytes in osteoarthritis by targeting PTEN. Biochem. Cell Biol. 2017, 95, 437-444. [CrossRef] [PubMed] 
213. Gabler, J.; Ruetze, M.; Kynast, K.L.; Grossner, T.; Diederichs, S.; Richter, W. Stage-specific mirs in chondrocyte maturation: Differentiation-dependent and hypertrophy-related miR clusters and the miR-181 family. Tissue Eng. Part A 2015, 21, 2840-2851. [CrossRef] [PubMed]

214. Zhai, X.; Meng, R.; Li, H.; Li, J.; Jing, L.; Qin, L.; Gao, Y. Mir-181a modulates chondrocyte apoptosis by targeting glycerol-3-phosphate dehydrogenase 1-like protein (GPD1L) in osteoarthritis. Med. Sci. Monit. 2017, 23, 1224-1231. [CrossRef] [PubMed]

215. Huang, X.; Schwind, S.; Santhanam, R.; Eisfeld, A.K.; Chiang, C.L.; Lankenau, M.; Yu, B.; Hoellerbauer, P.; Jin, Y.; Tarighat, S.S.; et al. Targeting the ras/mapk pathway with mir-181a in acute myeloid leukemia. Oncotarget 2016, 7, 59273-59286. [CrossRef] [PubMed]

216. Iliopoulos, D.; Jaeger, S.A.; Hirsch, H.A.; Bulyk, M.L.; Struhl, K. STAT3 activation of miR-21 and mir-181b-1 via PTEN and CYLD are part of the epigenetic switch linking inflammation to cancer. Mol. Cell 2010, 39, 493-506. [CrossRef] [PubMed]

217. Yao, Y.; Zhang, X.; Chen, H.P.; Li, L.; Xie, W.; Lan, G.; Zhao, Z.W.; Zheng, X.L.; Wang, Z.B.; Tang, C.K. MicroRNA-186 promotes macrophage lipid accumulation and secretion of pro-inflammatory cytokines by targeting cystathionine gamma-lyase in thp-1 macrophages. Atherosclerosis 2016, 250, 122-132. [CrossRef] [PubMed]

218. Wang, F.; Jiang, H.; Wang, S.; Chen, B. Dual functional microRNA-186-5p targets both FGF2 and RelA to suppress tumorigenesis of glioblastoma multiforme. Cell. Mol. Neurobiol. 2017, 37, 1433-1442. [CrossRef] [PubMed]

219. Li, Z.; Meng, D.; Li, G.; Xu, J.; Tian, K.; Li, Y. Overexpression of microRNA-210 promotes chondrocyte proliferation and extracellular matrix deposition by targeting hif-3alpha in osteoarthritis. Mol. Med. Rep. 2016, 13, 2769-2776. [CrossRef] [PubMed]

220. Phuah, N.H.; Azmi, M.N.; Awang, K.; Nagoor, N.H. Down-regulation of microRNA-210 confers sensitivity towards 1's-1'-acetoxychavicol acetate (ACA) in cervical cancer cells by targeting SMAD4. Mol. Cells 2017, 40, 291-298. [CrossRef] [PubMed]

221. Bavelloni, A.; Ramazzotti, G.; Poli, A.; Piazzi, M.; Focaccia, E.; Blalock, W.; Faenza, I. MiRNA-210: A current overview. Anticancer Res. 2017, 37, 6511-6521. [PubMed]

222. Liu, S.C.; Chuang, S.M.; Hsu, C.J.; Tsai, C.H.; Wang, S.W.; Tang, C.H. CTGF increases vascular endothelial growth factor-dependent angiogenesis in human synovial fibroblasts by increasing miR-210 expression. Cell Death Dis. 2014, 5, e1485. [CrossRef] [PubMed]

223. Zheng, X.; Zhao, F.C.; Pang, Y.; Li, D.Y.; Yao, S.C.; Sun, S.S.; Guo, K.J. Downregulation of miR-221-3p contributes to IL-1beta-induced cartilage degradation by directly targeting the SDF1/CXCR4 signaling pathway. J. Mol. Med. (Berl.) 2017, 95, 615-627. [CrossRef] [PubMed]

224. Xu, J.; Liu, Y.; Deng, M.; Li, J.; Cai, H.; Meng, Q.; Fang, W.; Long, X.; Ke, J. MicroRNA221-3p modulates Ets-1 expression in synovial fibroblasts from patients with osteoarthritis of temporomandibular joint. Osteoarthr. Cartil. 2016, 24, 2003-2011. [CrossRef] [PubMed]

225. Chou, W.W.; Wang, Y.T.; Liao, Y.C.; Chuang, S.C.; Wang, S.N.; Juo, S.H. Decreased microRNA-221 is associated with high levels of TNF-alpha in human adipose tissue-derived mesenchymal stem cells from obese woman. Cell. Physiol. Biochem. 2013, 32, 127-137. [CrossRef] [PubMed]

226. Yang, X.; Guan, Y.; Tian, S.; Wang, Y.; Sun, K.; Chen, Q. Mechanical and il-1beta responsive mir-365 contributes to osteoarthritis development by targeting histone deacetylase 4. Int. J. Mol. Sci. 2016, 17, 436. [CrossRef] [PubMed]

227. Xu, Z.; Xiao, S.B.; Xu, P.; Xie, Q.; Cao, L.; Wang, D.; Luo, R.; Zhong, Y.; Chen, H.C.; Fang, L.R. miR-365, a novel negative regulator of interleukin-6 gene expression, is cooperatively regulated by Sp1 and NF-kappaB. J. Biol. Chem. 2011, 286, 21401-21412. [CrossRef] [PubMed]

228. Wang, G.; Zhang, Y.; Zhao, X.; Meng, C.; Ma, L.; Kong, Y. MicroRNA-411 inhibited matrix metalloproteinase 13 expression in human chondrocytes. Am. J. Transl. Res. 2015, 7, 2000-2006. [PubMed]

229. Wang, H.; Zhang, H.; Sun, Q.; Wang, Y.; Yang, J.; Yang, J.; Zhang, T.; Luo, S.; Wang, L.; Jiang, Y.; et al. Intra-articular delivery of antago-mir-483-5p inhibits osteoarthritis by modulating matrilin 3 and tissue inhibitor of metalloproteinase 2. Mol. Ther. 2017, 25, 715-727. [CrossRef] [PubMed]

230. Xu, R.; Li, J.; Wei, B.; Huo, W.; Wang, L. MicroRNA-483-5p modulates the expression of cartilage-related genes in human chondrocytes through down-regulating tgf-beta1 expression. Tohoku J. Exp. Med. 2017, 243, 41-48. [CrossRef] [PubMed] 
231. Song, J.; Kim, D.; Lee, C.H.; Lee, M.S.; Chun, C.H.; Jin, E.J. MicroRNA-488 regulates zinc transporter SLC39A8/ZIP8 during pathogenesis of osteoarthritis. J. Biomed. Sci. 2013, 20, 31. [CrossRef] [PubMed]

232. Kim, J.H.; Jeon, J.; Shin, M.; Won, Y.; Lee, M.; Kwak, J.S.; Lee, G.; Rhee, J.; Ryu, J.H.; Chun, C.H.; et al. Regulation of the catabolic cascade in osteoarthritis by the zinc-ZIP8-MTF1 axis. Cell 2014, 156, 730-743. [CrossRef] [PubMed]

233. Rolauffs, B.; Rothdiener, M.; Bahrs, C.; Badke, A.; Weise, K.; Kuettner, K.E.; Kurz, B.; Aurich, M.; Grodzinsky, A.J.; Aicher, W.K. Onset of preclinical osteoarthritis: The angular spatial organization permits early diagnosis. Arthritis Rheumtol. 2011, 63, 1637-1647. [CrossRef] [PubMed]

234. Anderson, D.D.; Chubinskaya, S.; Guilak, F.; Martin, J.A.; Oegema, T.R.; Olson, S.A.; Buckwalter, J.A. Post-traumatic osteoarthritis: Improved understanding and opportunities for early intervention. J. Orthop. Res. 2011, 29, 802-809. [CrossRef] [PubMed]

235. Lieberthal, J.; Sambamurthy, N.; Scanzello, C.R. Inflammation in joint injury and post-traumatic osteoarthritis. Osteoarthr. Cartil. 2015, 23, 1825-1834. [CrossRef] [PubMed]

236. Rolauffs, B.; Kurz, B.; Felka, T.; Rothdiener, M.; Uynuk-Ool, T.; Aurich, M.; Frank, E.; Bahrs, C.; Badke, A.; Stockle, U.; et al. Stress-vs-time signals allow the prediction of structurally catastrophic events during fracturing of immature cartilage and predetermine the biomechanical, biochemical, and structural impairment. J. Struct. Biol. 2013, 183, 501-511. [CrossRef] [PubMed]

237. Rolauffs, B.; Muehleman, C.; Li, J.; Kurz, B.; Kuettner, K.E.; Frank, E.; Grodzinsky, A.J. Vulnerability of the superficial zone of immature articular cartilage to compressive injury. Arthritis Rheumtol. 2010, 62, 3016-3027. [CrossRef] [PubMed]

238. Behrendt, P.; Feldheim, M.; Preusse-Prange, A.; Weitkamp, J.T.; Haake, M.; Eglin, D.; Rolauffs, B.; Fay, J.; Seekamp, A.; Grodzinsky, A.J.; et al. Chondrogenic potential of IL-10 in mechanically injured cartilage and cellularized collagen aci grafts. Osteoarthr. Cartil. 2018, 26, 264-275. [CrossRef] [PubMed]

239. Behrendt, P.; Preusse-Prange, A.; Kluter, T.; Haake, M.; Rolauffs, B.; Grodzinsky, A.J.; Lippross, S.; Kurz, B. IL-10 reduces apoptosis and extracellular matrix degradation after injurious compression of mature articular cartilage. Osteoarthr. Cartil. 2016, 24, 1981-1988. [CrossRef] [PubMed]

240. Imgenberg, J.; Rolauffs, B.; Grodzinsky, A.J.; Schunke, M.; Kurz, B. Estrogen reduces mechanical injury-related cell death and proteoglycan degradation in mature articular cartilage independent of the presence of the superficial zone tissue. Osteoarthr. Cartil. 2013, 21, 1738-1745. [CrossRef] [PubMed] 